IZA DP No. 8630

Village Political Economy, Land Tenure Insecurity, and the Rural to Urban Migration Decision: Evidence from China

John Giles

Ren $\mathrm{Mu}$

November 2014 


\title{
Village Political Economy, Land Tenure Insecurity, and the Rural to Urban Migration Decision: Evidence from China
}

\author{
John Giles \\ World Bank and IZA \\ Ren Mu \\ Texas A\&M University and IZA
}

Discussion Paper No. 8630

November 2014

\author{
IZA \\ P.O. Box 7240 \\ 53072 Bonn \\ Germany \\ Phone: +49-228-3894-0 \\ Fax: +49-228-3894-180 \\ E-mail: iza@iza.org
}

\begin{abstract}
Any opinions expressed here are those of the author(s) and not those of IZA. Research published in this series may include views on policy, but the institute itself takes no institutional policy positions. The IZA research network is committed to the IZA Guiding Principles of Research Integrity.

The Institute for the Study of Labor (IZA) in Bonn is a local and virtual international research center and a place of communication between science, politics and business. IZA is an independent nonprofit organization supported by Deutsche Post Foundation. The center is associated with the University of Bonn and offers a stimulating research environment through its international network, workshops and conferences, data service, project support, research visits and doctoral program. IZA engages in (i) original and internationally competitive research in all fields of labor economics, (ii) development of policy concepts, and (iii) dissemination of research results and concepts to the interested public.
\end{abstract}

IZA Discussion Papers often represent preliminary work and are circulated to encourage discussion. Citation of such a paper should account for its provisional character. A revised version may be available directly from the author. 
IZA Discussion Paper No. 8630

November 2014

\section{ABSTRACT \\ Village Political Economy, Land Tenure Insecurity, and the Rural to Urban Migration Decision: Evidence from China*}

This paper investigates the impact of land tenure insecurity on the migration decisions of China's rural residents. A simple model first frames the relationship among these variables and the probability that a reallocation of land will occur in the following year. After first demonstrating that a village leader's support for administrative land reallocation carries with it the risk of losing a future election, the paper exploits election-timing and village heterogeneity in lineage group composition and demographic change to identify the effect of land security. In response to an expected land reallocation in the following year, the probability that a rural resident migrates out of the county declines by 2.8 percentage points, which accounts for 17.5 percent of the annual share of village residents, aged 16 to 50 , who worked as migrants during the period. This finding underscores the potential importance of secure property rights for facilitating labor market integration and the movement of labor out of agriculture.

JEL Classification: $\quad$ O12, O15, J61, Q15, R23

Keywords: migration, land tenure, property rights, China, village political economy

Corresponding author:

John Giles

Development Research Group

The World Bank

Mail Stop, MC 3-311

1818 H Street, NW

Washington, DC 20433

USA

E-mail: jgiles@worldbank.org

\footnotetext{
* Our work has benefitted from comments and discussions related to an earlier and very different paper (Giles, 2001) with Dwayne Benjamin, Loren Brandt, Andrew Foster, Steven Haider, Kaivan Munshi, Scott Rozelle and Duncan Thomas. This paper has improved with suggestions of Klaus Deininger, James Heckman, Chang-Tai Hsieh, Hongbin Li, Hidehiko Ichimura, Ghazala Mansuri, Albert Park, Nancy Qian, Scott Rozelle, John Strauss, Dali Yang and Xiaobo Zhang and participants in the 2011 NEUDC Conference at Yale University, the 2012 PAA Meetings in San Francisco, the 2012 China Economics Summer Institute, the 2012 UChicago-Renmin Symposium on Family and Labor Economics, and the 2013 ASSA Meetings. The authors gratefully acknowledge financial support from the US National Science Foundation for a survey collecting supplemental household and village data used for this study (SES-0214702, "Weak Property Rights and the Emergence of Labor Markets in Rural China"), and support for this paper from the Knowledge for Change Program at the World Bank.
} 


\section{Introduction}

An economy-wide structural shift from employment in agriculture to non-agricultural activities is a prominent feature of the development process. ${ }^{1}$ At the level of the household, or family, the shift of labor from agriculture to industry and commensurate movement out of rural areas often proceeds incrementally, with individual family members migrating to urban or manufacturing areas while leaving other members behind. An important aspect of this gradual process is that family members in rural and urban areas remain linked, and this arrangement often benefits the household in numerous ways. ${ }^{2}$ The decision to migrate, however, is shaped by institutional arrangements, both locally and in migrant destinations, that shape the benefits of migration and employment off-farm. If poor institutions limit the function of land, labor or credit markets, they may raise or lower the expected benefits to individuals and households from moving out of agriculture. When an individual's presence in the village and active work on land improves a household or family's claim to land, then such endogeneity of land tenure security may influence migration decisions and shape the process of structural change.

An abundance of theoretical research suggests that insecure property rights may have important impacts on productivity, factor allocation and economic development. ${ }^{3}$ A growing body of empirical research based on micro-data has tested these theoretical predictions in a range of settings, but with primary focus on the impact of rights on investments or agricultural production. ${ }^{4}$ More recent empirical

\footnotetext{
${ }^{1}$ The movement of labor from concentration in rural agricultural pursuits to urban-based industry figures prominently in many of the classic works in development economics (e.g., Kuznets, 1955; Lewis, 1954 and 1958; Ranis and Fei, 1961).

${ }^{2}$ Transfers from migrants may be an important source of investment funds if local credit markets do not function well (Woodruff and Zenteno, 2007), or alternatively, migrants may provide insurance for households which remain behind (Giles, 2006; Rosenzweig and Stark, 1989).

${ }^{3}$ The mechanisms through which property rights affect economic activity are context specific and depend on complementary institutions (Besley and Ghatak, 2009a; Katz and Owen, 2009). Besley ahd Ghatak (2009b) identify four mechanisms through which clear and secure property rights improve efficiency in resource allocation and productivity. Feder and Feeny (1991) and North (1990), for example, emphasize the importance of secure property rights in supporting economic development. Further, Acemoglu et al (2001) suggest that variation in protection of property rights across countries led to significant differences in subsequent economic performance.

${ }^{4}$ Evidence from the literature is mixed, though several studies support the view that secure land rights are investment-enhancing and may affect cultivation techniques adopted. Land tenure security in Ghana is associated
} 
research has highlighted the potential importance property rights in labor market outcomes, off-farm activities and migration. Do and lyer (2008) find that a land titling program in Vietnam led to increases in the proportion of cultivated land devoted to perennial crops and facilitated shifting of land to non-farm activities. In urban Peru, evidence shows that providing titles to urban residents leads to increases in labor supply of adults as well as stimulating investment in housing (Field 2007; Field 2005) ${ }^{5}$ Access to a formal land title is also found to increases Mexican emigration to the US (Valsecchi 2010). In Ethiopia a positive correlation is established between land transferability rights and internal migration (de Brauw and Mueller 2012).

In this paper, we examine how land tenure insecurity in China influenced the decision of rural residents to participate in migrant labor markets over the period from 1995 to 2003 . Researchers have documented considerable heterogeneity in the use of administrative land reallocation over this period (e.g., Rozelle and Li, 1998; Brandt et al, 2004), and further, the late 1990s also corresponded to a rapid increase in the scale of migration to China's cities. Across rural villages, the share of the registered local population working as migrants varied considerably, even within counties, and variations in tenure security offer one explanation for observed migration patterns. Identifying the effect of tenure insecurity on migration or labor allocation decisions is not straightforward: loss of land may simply reflect the choice of a household to farm less (or not at all) and to allocate labor to non-agricultural pursuits. Outcomes of village reallocation processes reflect unobserved bargaining between village leaders and farmers, and prior research has found that reallocations substitute, albeit imperfectly, for a market: through village leader intermediation, households that are more productive in agriculture

with more tree plantings and higher probability of investment (Besley, 1995), longer duration of land fallowing and higher subsequent agricultural production (Goldstein and Udry, 2008), and higher probability that tree crops will be planted when individualistic land use rights are protected (Bandiera, 2007). In China, higher risk of expropriation is associated with significant reduction in application of organic fertilizer (Jacoby, Li and Rozelle, 2002), and in Columbia, inhibited shifts into coffee production (Sanchez, Lopez-Uribe and Fazio, 2010). Other studies, however, cast doubt on the existence of a systematic influence of land tenure security on investment, and emphasize that informal rights may provide stable entitlements (Brasselle, Gaspart and Platteau, 2002).

${ }^{5}$ The effects of titling on residential investment are consistent with those from a "natural experiment" analysis of the allocation of property rights in Argentina (Galiani and Schargrodsky, 2005). 
receive land from households concentrated in other activities (e.g., Benjamin and Brandt, 2002). Thus, both observed and unobserved characteristics of individuals and households that are associated with loss of land may simply reflect household decisions to shift out of agriculture and the ability of younger and more educated residents to engage in non-agricultural activities.

Considering both the scale and rapid increase in rural-to-urban migration in China over this period, it may at first seem counterintuitive to spend much time dwelling on barriers to migration. Residents of rural China, however, have faced important institutional barriers to geographic mobility throughout the reform period, and rising rural-urban income gaps offer prima facie evidence that migration flows have not proceeded rapidly enough to offset differences in productivity growth between rural and urban areas (Park, 2008). Upon examination of micro data from rural China, it becomes apparent that there is tremendous heterogeneity across villages in levels of out-migration over the reform period, and that this period was also characterized by sharp increases in inequality within rural areas (Benjamin et al, 2005; Ravallion and Chen, 2007). Considerable effort has gone into studying the consequences of the household registration system (or Hukou system), ranging from rural-urban inequality (Liu, 2005) to under-sized cities with unexploited economies of scale (Au and Henderson, 2006). At the same time, there is a relative paucity of work describing how variation in land tenure security across rural China may have influenced migration decisions, with likely implications for differences in incomes and consumption across villages.

Over the period under study, there was considerable variation in de facto land tenure security across China's villages. Under China's constitution, rural land is the property of administrative villages, or collectives, but exclusive use rights are contracted out to individual households. As in many other developing countries, China has laws with provisions to formally protect individualistic land use rights, but enforcement mechanisms do not necessarily exist or function as intended (e.g, Benjamin and Brandt, 2002; Brandt et al, 2004; Dieninger and Jin, 2009; Jacoby et al, 2002). 
In this paper, we use the timing of elections to identify the risk that village residents will lose land during a reallocation in the following year. Recognizing that election timing itself may be correlated with other time-varying village factors affecting reallocation and migration decisions, we develop a model in which the benefits and costs of reallocating land in the next year vary over the election cycle and with other village characteristics: the initial share of the village in the main lineage group (also known as kinship group or patrilineal clan) and exogenous demographic change (number of deaths of village residents). In the empirical approach that follows, our model suggests controlling directly for election timing, and identifying the expected risk of reallocation in the next period using interactions of election timing indicators with two other village characteristics: the initial (1995) share of households belonging to the main lineage group and deaths per 100 village residents in the current year, respectively. To highlight the heterogeneity across villages in political cost of reallocation decisions, we present evidence suggesting that a village leader's probability of losing an election subsequent to a reallocation is higher in villages in which a larger share of the village is in a main lineage group (and where informal rental markets are better functioning), and lower in villages experiencing more significant demographic change in the previous year (through deaths per hundred registered residents). Next we show that, after controlling for election timing, the probability of a reallocation in the next year falls with increases in the share of the village in the largest lineage group and when an election is scheduled in the current or following year. The interaction of election-timing and lineage group share, together with the interaction of election-timing and deaths per hundred in the village, is then exploited to identify the effect of land reallocation risk on individual migration decisions of those village residents between 16 and 50 years of age.

Below, in Section 2 we present a theoretical framework to highlight factors affecting the reallocation decision of a village leader and the reaction of farm households and working-age adults. The model highlights potential loss of a subsequent election as a "cost" the village head may incur in supporting a 
reallocation. Next, we examine how potential loss of land in a future land reallocation influences a household's decision to allocate labor between farming on household managed land and employment as a migrant in the urban wage sector. Section 3 develops the empirical strategy of the paper and discusses plausibility of important identification assumptions. Empirical results are presented in Section 4 and a final section concludes.

\subsection{Theoretical Framework}

\subsection{The Land Reallocation Decision of the Village Leader}

A village head seeks to maximize the expected gain from a land reallocation, and will only work to implement a reallocation if the benefits of doing so exceed the costs. One "cost" consideration is the possibility that subsequent election outcomes will be affected by the head's land reallocation initiatives, or possibly, the failure to reallocate.

We assume the leader maximizes utility over two time periods. In the first period he (or she) decides whether to reallocate land or not; a village election, exogenously scheduled, occurs in period two and the incumbent leader runs for reelection. ${ }^{6}$ Land reallocations may be implemented for a variety of reasons. Village leaders may reallocate land in order to promote equitable access to land among villagers, to improve labor-land matching in the absence of a functioning land rental market, or to seek private gains by extracting rents in the reallocation process (Brandt, Rozelle, and Turner, 2004). ${ }^{7}$ Thus, each reallocation of land may benefit not only the village as a whole but also the head personally, both of which are taken into account by the head. The benefits for the village are achieved through either an equity or efficiency gain. The leader's personal gain may reflect the returns associated with raising

\footnotetext{
${ }^{6}$ There are no term limits for village heads, so we assume incumbent leader automatically runs for reelection. Changing this assumption would not affect the essential implications of the model.

${ }^{7}$ Beyond a demographic rule, other empirical evidence for the equity hypothesis is scant, but both the efficiency and the rent seeking arguments are supported by Brandt, et al.
} 
village output through land reallocation, or benefits from either monetary or in-kind bribes, or in the form of a political gain reflected by increased support in subsequent elections from those residents supporting a reallocation. The cost to the leader has two components: a management cost (time and effort spent organizing meetings, solving disputes and implementing the reallocation); and a "political cost" associated with decrease in the support for the leader due to a loss of land experienced by some households, or distaste for a leader suspected of taking side-payments or favoring some residents in the reallocation process. Along with the costs and benefits, uncertainty plays a pivotal role in the leader's decision. Even in the absence of a land reallocation, the leader may be uncertain about future election results. Land reallocation adds on to that uncertainty since not all villagers are equally affected by reallocations and the net impact on election is undetermined ex ante. Among many village characteristics potentially influencing the costs and benefits of land reallocations, we focus on two: demographic change, proxied by death per hundred registered residents, and village linage composition, measured by the share of households in the largest lineage group. We will explain the rationale for focus on these characteristics below.

We begin by assuming that the village head's value function at time one is $V_{1}\left(\pi^{v}, \theta, d, f^{v}\right)$ where $\pi^{v}=1$ if the head calls for a land reallocation and $\pi^{v}=0$ otherwise; $\theta$ denotes village characteristics unobservable to researchers; $d$ represents deaths of registered residents of the village, $f^{v}$ is the share of households from the village in the largest lineage group (also known in the literature as patrilineal clan or kinship group). Utility in the second period depends on whether the leader is reelected or not. Let $U_{2}(1)$ denote the utility at time two if the head is reelected and $U_{2}(0)$ if not reelected. Assume that the head has a probability $p^{*}$ of being reelected if he doesn't call for a reallocation, and will lose with probability $\left(1-p^{*}\right)$. With no land reallocation $\left(\pi^{v}=0\right)$, the first period value function takes the form:

$$
V\left(0, \theta, d, f^{v}\right)=\beta p^{*} U_{2}(1)+\beta\left(1-p^{*}\right) U_{2}(0)
$$


where $\beta$ is the time discount factor. If the village head decides to reallocate land $\left(\pi^{v}=1\right)$, then the value function will reflect both the benefits and costs of reallocation, as in (2) below.

$$
V\left(1, \theta, d, f^{v}\right)=B^{v}\left(\theta, d, f^{v}\right)+\bar{M}-\bar{C}+\beta p\left(\theta, d, f^{v}\right) U_{2}(1)+\beta\left[1-p\left(\theta, d, f^{v}\right)\right] U_{2}(0)
$$

$B^{v}\left(\theta, d, f^{v}\right)$ denotes the benefits of the reallocation to the village as a whole, $\bar{M}$ is the head's personal gain, and $\bar{C}$ is the management cost of reallocation. With reallocation, the head's reelection probability is a function of how the reallocation interacts with village characteristics, which we represent as $p\left(\theta, d, f^{v}\right)$. The village leader will relocate when his, or her, gain from doing so is positive, or:

$$
\Delta V=B^{v}\left(\theta, d, f^{v}\right)+\bar{M}-\bar{C}+\beta\left\{\left[p\left(\theta, d, f^{v}\right)-p^{*}\right] U_{2}(1)+\left[p^{*}-p\left(\theta, d, f^{v}\right)\right] U_{2}(0)\right\}>0
$$

To understand how villages vary with respect to both demographic change and heterogeneity in lineage group composition, we evaluate derivatives of $\Delta V$ with respect to the number of deaths in the village and share of village in the main lineage group, respectively. The derivative of (3) with respect to deaths is:

$$
\frac{\partial \Delta V}{\partial d}=\frac{\partial B^{v}\left(\theta, d \cdot f^{v}\right)}{\partial d}+\beta \frac{\partial p\left(\theta, d, f^{v}\right)}{\partial d}\left[U_{2}(1)-U_{2}(0)\right]
$$

As land reallocation may improve the land-labor match, we assume that a village benefits more from land reallocation subsequent to more deaths of registered residents, or, $\frac{\partial B^{v}\left(\theta, d, f^{v}\right)}{\partial d}>0$, and further, that the probability of being reelected is independent of deaths, or $\frac{\partial p\left(\theta, d, f^{v}\right)}{\partial d}=0 .{ }^{8}$ Under the assumption that a village head prefers to be reelected, $U_{2}(1)-U_{2}(0)>0$, we expect that $\frac{\partial \Delta V}{\partial d}>0$

\footnotetext{
${ }^{8}$ We emphasize death of registered residents as prior allocation of land under a demographic rule was determined by household size as reflected in legal residential registration, which differs from physical presence in the household and village
} 
and a village head is more likely to call for a reallocation if the village experiences larger population change.

Next, we evaluate the derivative of (3) with respect to the initial share of village in the largest lineage group, or:

$$
\frac{\partial \Delta V}{\partial f^{v}}=\frac{\partial B^{v}\left(\theta, d, f^{v}\right)}{\partial f^{v}}+\beta \frac{\partial p\left(\theta, d, f^{v}\right)}{\partial f^{v}}\left[U_{2}(1)-U_{2}(0)\right]
$$

As we will show shortly, there are more active land rental markets in villages where a higher share of households are from the same patrilineal clan, implying that use of administrative mechanisms to achieve land transfers not be as important as in more heterogeneous villages. This has two implications in the context of our model. First, we expect the benefits to the village from reallocation to be lower when the share of households in the largest lineage clan is greater: $\frac{\partial B^{v}\left(\theta, d, f^{v}\right)}{\partial f^{v}}<0$. Second, the net political gain to the head from reallocation is smaller in more homogenous villages, that is $\frac{\partial p\left(\theta, d, f^{v}\right)}{\partial f^{v}}<0$. Thus, the decision of the village head over whether or not to reallocate land before an election depends crucially on the extent to which a significant share of the village is from the same lineage group. Therefore, we expect the village leader's benefit to reallocation will decline with increases in the lineage group share, or $\frac{\partial \Delta V}{\partial f^{v}}<0$, implying that heads of the villages with more households in the largest family lineage group are less likely to call for a land reallocation right before a village election. The land reallocation decision can thus be considered as a function of, among other things, the share of the village in the largest patrilineal clan and whether or not the village head will face an election in the following period, E. We express the head's decision in general form as:

$$
\pi^{v}=G\left(\theta, d, f^{v}, E\right)
$$

\subsection{The Household Labor Allocation Decision}

Assume a representative household in the village lives for two periods, initially endowed with land $L_{0}$ and with total labor normalized to 1 . In the first period, the household allocates labor between the 
urban labor market and farming. In the second period, household members work on the family farm (and any migrants are assumed to have returned home, or "retired" from migrant wage employment). Migrant labor time is denoted by $m$ with $0 \leq m \leq 1$, and thus available labor time devoted to local farming is $(1-m)$. Letting $w$ be the prevailing wage rate in the urban labor market, household income from migrant labor can be written as $w m$. The total agricultural output in period one can be written as $f\left(L_{0},(1-m)\right)$. The household's initial land endowment is subject to reallocation by the village head, but the outcome of the reallocation decision is not known until the second period. Delay in realization of the reallocation introduces uncertainty into the household labor allocation decision in the first period, which will be based on, among other things, perceived land tenure security. Let $\widehat{\pi^{v}}$ denote the probability that the village leader will initiate a significant land reallocation in period two. The perceived share of a household's land that could be lost in a reallocation is denoted by $s$, and is a function of household agricultural productivity $\delta$ and the share of labor devoted to urban sector $(m)$. In the second period, the expected amount of land can be expressed as $\left[1-\widehat{\pi^{v}} S(m, \delta)\right] L_{0}$, with the agricultural output $f\left(\left[1-\widehat{\pi^{v}} S(m, \theta)\right] L_{0}, 1\right)$, and the household's expectation over the probability of reallocation, $\widehat{\pi^{v}}$, will be formed by observables and unobservables in (6).

If the price of agricultural produce is normalized to 1 , the household will maximize utility by choosing the optimal share of labor time in migrant employment, $m$, during the first period:

$$
V(U)=\max _{m}\left\{f\left(L_{0},(1-m)\right)+w m+\beta f\left(\left[1-\widehat{\pi^{v}} s(m, \delta)\right] L_{0}, 1\right)\right\}
$$

It follows that the first order condition for an interior solution is:

$$
w=f_{2}+\beta f_{1} \widehat{\pi^{v}} S_{1} L_{0}
$$

where the subscripts 1 and 2 indicate the derivative of the function with respect to its first and second argument, respectively. This equation dictates that the optimal share of labor allocated to the urban sector is such that the discounted value of marginal product of labor on the farm over the two periods is equal to the wage in the urban sector. 
To assess how changes in the probability of village land reallocation influence the household's migration decision, we apply the implicit function theorem to derive the following relationship from equation (8): ${ }^{9}$

$$
\frac{d m}{d \widehat{\pi^{v}}}=\frac{\beta s_{1} L_{0}\left(f_{11} \widehat{\pi^{v}} s L_{0}-f_{1}\right)}{\beta f_{1} \pi^{v} s_{11} L_{0}-\beta f_{11}\left(\widehat{\pi^{v}} s_{1} L_{0}\right)^{2}-f_{22}}
$$

Assuming that farming follows a well-behaved production function, the partial derivatives with respect to land and labor have the standard features $f_{1}>0 ; f_{2}>0 ; f_{11}<0 ; f_{22}<0$; and $f_{12}>0$. As land reallocation will likely improve the match of agricultural labor to land, it is sensible to assume that that the perceived share of land that a household might lose is positively related to the labor devoted to the urban sector. In a notional form, it is expressed as $s_{1}=\frac{\partial s}{\partial m}>0$, and is the marginal cost of migration in terms of the share of land that could be lost in a reallocation. If the share of land lost in a land reallocation due to migration increases with migration, or $s_{11}>0$, then the derivative of migration with respect to the probability of land reallocation is negative $\left(\frac{d m}{d \widehat{\pi}^{v}}<0\right)$, and the share of labor allocated to the urban sector will decrease. However, if the cost of migration is decreasing, or $s_{11}<0$, then the sign of $\frac{d m}{d \widehat{\pi}^{v}}$ is undetermined.

The model implies that the impact of an expected future land reallocation on individual and household labor allocation decisions is an empirical question. To identify the effects of reallocation risk on migration, we utilize information embedded in equation (6), and exploit heterogeneity across villages in the effects of election timing on reallocation. Heterogeneity in election timing is picked up through interactions of election-timing indicators and two village level variables: initial share of the village in the largest lineage group $\left(f^{v}\right)$ and number of deaths among village registered residents.

\footnotetext{
${ }^{9}$ Let $F=w-f_{2}-\beta f_{1} \widehat{\pi^{v}} S_{1} L_{0}$ and under the implicit function theorem $\frac{d m}{d \widehat{\pi}^{v}}=-\frac{\frac{\partial F}{\partial \widetilde{\pi v}^{v}}}{\frac{\partial F}{\partial m}}$. We then note that $\frac{\partial F}{\partial \widehat{\pi}^{v}}=$ $\beta s_{1} L_{0}\left(f_{11} \widehat{\pi^{v}} s L_{0}-f_{1}\right)$ and $\frac{\partial F}{\partial m}=-\beta f_{1} \pi^{v} s_{11} L_{0}+\beta f_{11}\left(\widehat{\pi^{v}} s_{1} L_{0}\right)^{2}+f_{22}$ and solve for $\frac{d m}{d \widehat{\pi}^{v}}$.
} 
The model highlights the way that both factors influence the relationship between village political economy and migration risk, and mechanisms through which a household's potential loss of land may influence the decision to participate in the migrant labor market. Within the household, the migration ability of individuals will vary with gender, age and educational attainment of different household members. In our empirical strategy below, we examine how future village-level reallocation decisions influence individual migration decisions, while controlling for household and village level factors that may influence exposure to risk. Our model suggests that households recognize that lineage group differences, demographic change and proximity to an election, among other unobserved factors, influence a household's perception of the risk of reallocation. In our identification strategy below, we exploit these observable differences to identify the effect of a future reallocation on current migration decisions.

\subsection{Empirical Strategy}

\subsection{Data Source and Descriptive Statistics}

For our primary analysis, we make use household and village surveys conducted in fifty-five villages of four provinces (Anhui, Henan, Jiangsu and Shanxi) from August to October 2004 in collaboration with the Research Center for Rural Economy (RCRE) at the Ministry of Agriculture. This survey, supplemental to the annual RCRE survey, enumerated all 3,999 households in the 2003 wave of the RCRE panel for these four provinces, allowing us to match villages and households from the 2004 supplemental survey with a historical panel of villages and households that RCRE surveyed annually from 1986 to $2003 .{ }^{10}$ As

\footnotetext{
${ }^{10}$ Both authors on this paper worked extensively on the funding, and with RCRE, on the design and implementation of the supplemental survey (Loren Brandt was also a key participant in this effort). A detailed discussion of a larger nine-province sample from the RCRE panel dataset (translated from Chinese as the "National Fixed Point Survey"), including discussions of survey protocol, sampling, attrition, and comparisons with other data sources from rural China, can be found in the data appendix of Benjamin, Brandt and Giles (2005). Several useful resources, including original documentation from RCRE on the survey and sampling (and translations), are available at: sites.google.com/site/decrgjohngiles/datasets. Also available at the link are drafts of the supplemental household surveys conducted in four provinces (2004 Rural Household Social Network, Labor Allocation and Land Use Survey)
} 
our primary focus is on the migration decision, we make use of individual level information on labor allocation decisions of current and past household members from 1995 onward. Individual-level data collected in the supplementary survey included retrospective information on the current residence, migration and employment history of all individuals who had been household members at any time since 1995. By including information on former residents, primarily adult children of the household head who left after the 1995 base year, the supplemental survey allows us to complement household-level information from the annual surveys and makes it possible to examine individual migration decisions over time. At the village level, the supplemental survey provides detail on family lineage groups, significant land reallocations since 1991, land use rights, village elections, and turnover of village leaders. The supplementary data are matched with the RCRE regular household panel survey data from these four provinces, and allow us to characterize future reallocation risk based on the gross share of land subject to reallocation in the following year. ${ }^{11}$ From the RCRE household panel, we obtain information on annual household consumption and land holding. Further, the RCRE village panel includes many of the descriptive statics on crime and conflict that inform our understanding of how village cohesiveness may vary with the size of the largest lineage group.

In the supplemental survey, a group of respondents at the village level identified years in which significant land reallocations were carried out at either the level of the village or within several village small groups. ${ }^{12}$ Also enumerated were estimates of the number of households that faced some reallocation. In Table 1, we report summary statistics for instances in which land reallocations were significant enough that more than 10 percent of households in the village experienced loss of land in a

and supplemental village surveys conducted in eight provinces (2004 Village Governance Survey and Land Use Survey).

${ }^{11}$ While the annual surveys allow one to distinguish differences in household managed land across years, documentation accompanying the survey makes clear that these differences may reflect either land transferred informally to family members or changes due to administrative reallocations. Further, year-to-year changes reflect net changes to land, not the gross amount of land that was subject to reallocation.

${ }^{12}$ These included current and past village accountants and leaders of village small groups (cun xiaozu). 
reallocation. We choose 10 percent as our threshold for reallocation as this level typically implies that reallocation occurred in more than one village small group (cun xiaozu) during the year, and were thus significant enough to require village leader involvement. Results of our analysis below are robust to variation around this threshold. Significant reallocations do not occur with great frequency, as the average annual share of villages experiencing a reallocation was 19 percent, but for some years and provinces over the 1995-2003 period, reallocation could be quite significant. For example, more than 80 percent of villages in Jiangsu experienced a large-scale land reallocation in 1998, as did more than 40 percent of villages in Henan during the same year, which was consistent with the "second-round" of land contracting in the province. ${ }^{13}$ In Anhui and Shanxi, more land reallocation occurred in 1995 and 1999, respectively. Conditional on the occurrence of a village-wide reallocation, an average of one-third of households are affected, with considerable variation by province and over time. For example, in 1998 when "second-round contracting" was carried out in Henan province, 80 percent of households were affected. In 2003, however, only 13 percent of households faced reallocation.

By 2003, all but one village in the sample had had at least one village election. Table 2 provides annual information on share of villages reporting regularly scheduled elections. Two distinct features of elections are important to flag. First, election timing varies within province. If there was no variation, we would expect to find that the entire province would be on the same election cycle. Second, the election cycle varies both within and across provinces. While this may partially reflect recall errors in reports of election timing, it also reflects the fact that elections were less "regular" before the Organic Law, regulating, village administrations including elections, was passed in 1998.

\footnotetext{
${ }^{13}$ The first-round contract period was 15 years, but the starting year differed across provinces. When the firstround contract expired, the second -round contracting, often implemented with a large-scale land reallocation, entailed new contracts between the village collective and households, normally with longer contract periods. Of course, to degrees that varied across villages, reallocation risk was present regardless of whether or not the end of the contract term had been reached.
} 
Migration rates (the share of registered rural residents working as migrants) of the sample of roughly 7000 individuals aged 16 to 50 over the 1995 to 2002 period are reported in Table 3 and Figure 1. On average, 16 percent of the sample had experience working outside of their home county. Consistent with the trends observed in other panel data (e.g., the CHNS), the share of residents working as migrants tripled from 9 percent in 1995 to 27 percent in 2002. Migration is clearly correlated with age, gender and education level, which will be important for the empirical specification developed below. Even as migrant employment increases at all ages over the time-period under study (Figure 1), within any year the probability of working as a migrant declines after age 25 for both genders. More specifically, at any age, men have a higher migration rate than women, and there is no sign that the gender gap is closing over time. The young are more likely to migrate than the old, and so are the more educated.

\subsection{Specification and Identification}

One implication highlighted in the model is that, conditional on individual heterogeneity, an increase in the probability of land reallocation in the village during the following period may decrease an individual's propensity to work as a migrant. Our theoretical framework thus suggests estimating the following model for the migration decision:

$$
M_{i j t}=\alpha_{0}+\alpha_{1} R_{j t+1}+\boldsymbol{X}_{i j t}^{\prime} \boldsymbol{\alpha}_{2}+\boldsymbol{H}_{i j t}^{\prime} \boldsymbol{\alpha}_{3}+\boldsymbol{V}_{j t}^{\prime} \boldsymbol{\alpha}_{4}+Y_{p \times t}+\boldsymbol{e}_{j}^{\prime} \boldsymbol{T}+v_{i j}+\varepsilon_{i j t}
$$

in which migration of individual $i$ in village $j$ in year $t, M_{i j t}$, is a function of an expected village land reallocation in year $t+1, R_{j t+1}$, where expectations of forward-looking village residents will informed by local knowledge of factors influencing reallocation decisions. Also included are characteristics of the individual $\left(\boldsymbol{X}_{i j t}\right)$, his/her household $\left(\boldsymbol{H}_{i j t}\right)$ and time-varying village effects $\left(\boldsymbol{V}_{j t}\right)$ control for local economic changes that may influence migration. Additionally, province-year effects $Y_{p \times t}$ are included to control for province-wide macroeconomic shocks, and village fixed effects, $e_{j}$, which are interacted with 
a time trend $T$ to allow for village-specific trends in migration. Finally, there may be unobserved individual characteristics, $v_{i j}$ and $\varepsilon_{i j t}$ is an idiosyncratic error term.

Evident in this specification are both observed and unobserved sources of heterogeneity that we must consider in examining the effects of reallocation risk on migration decisions. The detailed information available in the RCRE household and village panel data from 1995 to 2003, and the supplementary survey data collected in 2004 are of tremendous use, and allow us to include a large set of control variables in the regression analysis. More specifically, included in $\boldsymbol{X}_{i j t}$ are individual gender, age, years of schooling. Recognizing from Figure 1 that there are important trends associated with age and gender, $\boldsymbol{X}_{i j t}$ includes age- and gender-specific time trends. As previous analysis has shown that parent health status affects the migration decision of adult children and that the impact varies with the number of siblings (Giles and $\mathrm{Mu}, 2007)$, individual regressors $\left(\boldsymbol{X}_{i j t}\right)$ also include controls for whether father and mother are still alive and number of siblings, regardless of their current residence in the household, thus reducing bias associated with endogenous household composition. Household characteristics $\left(\boldsymbol{H}_{i j t}\right)$ include land per capita, consumption per capita and working-age residents (aged 16-60) as a share of household members (excluding individual $i$ ). In addition, we control for the number of young women (aged 19-24) and the number of young men (aged 21-26) in the family, which proxy for potential household demographic changes caused by marrying-out or marrying-in, and which may be correlated with both land reallocation risk and a household member's migration decision. Among village characteristics variables $V_{j t}$ are village population (controlling for scale effects), average village income per capita, land per capita, the number of village cadres (controlling for features of governance), share of village cadres with high school education or above (quality of governance), a village land per capita gini index, and two variables capturing village election timing: indicators for whether the observation is in the year of or year before a regularly scheduled election. 
Even with a large set of control variables, we cannot rule out the possibility that individual unobservable traits, such as agricultural productivity, ability, risk aversion or household socioeconomic position within the village may affect both individual migration decisions and exposure to land reallocation risk. ${ }^{14}$ One sensible way of controlling for these individual fixed effects is to take firstdifferences of (10), which yields:

$$
\Delta M_{i j t}=\beta_{1} \Delta R_{j t+1}+\Delta \boldsymbol{X}^{\prime}{ }_{i j t} \boldsymbol{\beta}_{2}+\Delta \boldsymbol{H}^{\prime}{ }_{i j t} \boldsymbol{\beta}_{3}+\Delta \boldsymbol{V}^{\prime}{ }_{j t} \boldsymbol{\beta}_{4}+\Delta Y_{p \times t}+\boldsymbol{e}_{j}+\Delta \varepsilon_{i j t}
$$

The effect of land tenure insecurity is now identified from the difference in expected future reallocations and on changes in migration decisions over time. Note that village fixed effects, which remain after differencing the village-specific trend, control for the effects of geographic location (including the local economy and institutional features affecting migration) on changes in migration over time. Trends associated with age and gender, which we had allowed for in (10), will show up in levels after differencing in (11).

Differencing, as in (11), eliminates fixed unobservable determinants of migration, but one might be concerned that there remain important unobserved time-varying determinants of migration that are also correlated with changes in land tenure security. For example, both local economic shocks and demographic changes in the village may influence migration decisions and could plausibly affect the occurrence and the scope of land reallocation in the village, thus biasing the estimate of $\beta_{1}$. To obtain consistent estimates of the effect of land tenure security in equation (11), we consequently construct instruments for the change in future village land reallocation that are unlikely to be direct determinants of changes in an individual's migration decision. For this purpose, we exploit the interaction of three sources of variation at the village level to identify the impacts of significant land reallocation within the village. The first variation is the timing of the village election $\left(E_{j t}\right)$, the second is the number of deaths

\footnotetext{
${ }^{14}$ The specific lineage group to which the household belongs might have a direct impact on ability and preferences for migration. An individual from a family with a less dominant position may not find positions in local enterprises or government as easily, and migration may look more appealing.
} 
per hundred in the village $\left(D_{j t}\right)$, and the third is the share of village households in the main patrilineal clan in the first period of the panel $\left(F_{j 0}\right)$. Using these three components and two interactions, the change in land reallocation between time $t+1$ and $t$ can be characterized by the following expression:

$$
\Delta R_{j t+1}=G\left(E_{j t}\right)+\gamma_{1} F_{j 0}+\gamma_{2} D_{j t}+F_{j 0} \times G\left(E_{j t}\right)+D_{j t} \times G\left(E_{j t}\right)
$$

Election Timing $\left(\boldsymbol{E}_{j t}\right)$. The rationale for using information on election timing, $E_{j t}$, to identify the risk of land reallocation is based on the fact that village committees, the primary self-governance organization in rural villages, have legal authority over reallocation of land in the village, but the village leadership may be sanctioned by village residents through the electoral process. ${ }^{15}$ The selection procedure for the chair of village committee, also known as the village head, has undergone multiple reforms since the early 1980 s, but by 1998 , ten years after the enactment of a provisional law on the election of village committees, the majority of villages across China were electing their village head through popular vote. ${ }^{16}$ Previous studies have shown that village elections seem to affect both the frequency and the scale of land reallocations. ${ }^{17}$ Further, as evident in Figure 2, there are apparent variations in reallocation depending on the point in the election cycle.

\footnotetext{
${ }^{15}$ Article 5 of the the Organic Law of Villagers' Committees enacted in 1998 stipulates, "The villagers committee shall, in accordance with the provisions of laws, administer the affairs concerning the land and other property owned collectively by residents of the village."

${ }^{16}$ The 1987 provisional Organic Law of Villagers' Committee mandated that all villages conduct elections to select village committee members. The provisional law took effect in 1988 and was implemented in a decentralized and experimental manner. By 1993, 22 provinces had formulated procedures for implementing the provisional Organic Law in village elections (CRLSRT, 2000). In 1998 the Organic Law was further amended and formally took effect. Based on the revised Organic Law, provinces updated their procedures of implementations of the law.

${ }^{17}$ For example, Brandt, Rozelle and Turner (2004) find that a contested election in the year of land reallocation or the year prior to the land reallocation shortened the duration between two land reallocations, and also reduces the size of the reallocation. Deininger and Jin (2009) show that after the passing of Rural Land Contracting Law in 2003, illegal land reallocation (land reallocation without ratification from the village assembly and permission from township and county government) became much less frequent in villages where both the village head and communist party secretary are elected. Other research has found that the introduction of village elections has had a positive impact on public good provisions (Martinez-Bravo et al, 2014).
} 
One important feature of the timing of village elections is that they are exogenously determined at the county level, or occasionally at the township level, by the "leading group for village elections." ${ }^{18}$ The leading group at the county level is the most important agent in planning, organizing and supervising elections in the villages under its administration, and in some provinces the leading group at the township level is charged with the same responsibility (CRLSRT 2000). ${ }^{19}$ One of the major responsibilities of the leading groups is to educate villagers regarding election protocol and to encourage voter turnout. For this purpose, a county-wide (or township-wide) information campaign is typically launched before each election. Consequently, the timing of village elections, in terms of election year, is fairly uniform within one county (Zhang et al. 2004), although the timing of elections varies within a province (Table 1) and even more so across regions (O'Brien and $\mathrm{Li}, 2000) .{ }^{20}$

Even though election years, specified by county or township leading groups, are generally exogenous to the characteristics of each village, one might be concerned that some village elections may be initiated by "endogenous leadership turnover." Such a process may occur when a conflict between village residents and village leaders becomes serious enough that township or county authorities intervene, dismiss the leader and schedule a new election. The supplemental village survey used for our analysis helpfully allows us to exclude elections that occurred right after a resignation or dismissal of a village head. In our analysis, we exclude such elections and exploit the timing of "regularly scheduled" elections.

For two reasons, we might expect some measurement error in election year timing. First, election information is collected retrospectively, and may be prone to recall error. Second, in order to encourage

\footnotetext{
${ }^{18}$ Appendix table A1 summarizes the regulations governing elections in the four provinces (Anhui, Henan, Jiangsu and Shanxi), including a discussion of their organizational structure and timing.

${ }^{19}$ The leading group at the county or township level is composed of multiple county or township officials, often from different agencies including the bureau of civil affairs, the department of public relations and the bureau of public security.

${ }^{20}$ The exact date of election can vary across villages within a county because an election committee at the village level has the right to decide on the voting date and location (see summary of related documents in Appendix Table A1).
} 
participation of migrants who frequently return to visit families during this period, elections in many villages are scheduled around the Chinese New Year (Tang, 2004). We therefore characterize election timing with two indicator variables, for whether the observation year is one year before, or the year of an election.

$$
G\left(E_{j t}\right)=v_{1} \text { OneYearBefore }{ }_{j t}+v_{2} \text { The ElectionYear }{ }_{j t}
$$

We will then consider below the relationship between election timing and subsequent reallocations. As the effects of election timing on both expected future reallocations and migration is likely to differ with important features of the village, we introduce two interaction terms to exploit this heterogeneity for our identification.

Deaths Per Hundred Residents $\left(\boldsymbol{D}_{\boldsymbol{j} t}\right)$. Empirical evidence has shown that the periodic reallocation of land among villagers is a response to demographic change (Kung, 1995, 2000; Liu et al., 1998). Thus, we also include the number of deaths per hundred $\left(D_{j t}\right)$, as an indicator for how population change of registered residents may create expectations of a future reallocation. Figure 3 demonstrates this relationship: after a threshold of two deaths per hundred residents, the probability of a significant land reallocation increases with the number of deaths per hundred in the village. Interactions of election timing and deaths in the village (apart from the household of the potential migrant) are preferred, as interactions of other demographic changes may be related to systematic decisions that vary with election timing.

Share of Households in Largest Lineage Group $\left(\boldsymbol{F}_{j 0}\right)$. The composition of family lineage clans within villages is frequently viewed as an important determinant of how well informal institutions function within rural China's villages. The share of village households in the largest lineage group is a convenient proxy for homogeneity of lineage groups. Residents belonging to the same lineage group share common patrilineal ancestry and maintain closer social ties, and therefore family lineage may substitute for formal institutions in solving information and enforcement problems, help to mitigate social conflicts 
and improve local governance (Xu and Yao, 2009). Tsai (2007) argues that villages with more homogenous family lineage generally enjoy better provision of public goods. In the RCRE panel used in this paper, the relationship between homogeneity of family lineage and incidence of village land reallocation is clearly negative (Figure 4) - the larger the share of households in the same patrilineal clan in the base year (1995), the less likely it is to have a significant land reallocation during the 19952003 period.

This negative correlation between homogeneity of lineage and land reallocations may be explained by two distinct features from which more homogenous villages differ from less homogenous ones. First, mutual trust between villagers built through common family lineage may lead to less conflict, which may facilitate land rental transactions and ease the need for land reallocation. Indirect evidence of less conflict in homogenous villages is shown in Figure 5. Both civil disputes and reported criminal acts decrease with the share of households in the largest lineage group. ${ }^{21}$ Moreover, disputes over land are far less likely to be the major cause of conflict among villagers with large family lineage clans, but are frequently the most important source of conflict in villages which lack them (Figure 6, left axis). Further, land rental activities are much less frequent in villages without major family lineage groups (Figure 6, right axis), while villages with large family lineage clans rely less on land reallocation to improve the match between labor and land.

Apart from greater levels of trust and reduced conflict, better monitoring of leaders in villages with dominant lineage groups provide an additional explanation for reduced reallocation activity. Improved monitoring in more homogenous villages reduces the scope for using actual or threatened reallocation as a rent-seeking device (Xu and Yao, 2009; Tsai 2007). Consistent with the monitoring argument, we find that the village representative assembly tends to play a much more important role in the decision-

\footnotetext{
${ }^{21} \mathrm{Xu}$ and Yao (2009) report that both civil disputes and criminal cases are lower in those villages in which the head is elected from the largest family lineage clan.
} 
making of villages with dominant family clans than in those without. ${ }^{22}$ As shown in Figure 7 , when more households are in the largest family lineage clan, the village representative assembly is more likely to be authorized to examine village financial records (left axis) and is also more likely to report instances in which it exerted monitoring authority by overturning decisions of the governing party or villagers' committees (right axis). Information from village elections also suggests other dimensions in which villages with large lineage clans may be more "democratic," as these villages tend to have more candidates and candidates are more likely to make public speeches during their election campaigns (Figure 8).

If both more land rental and better monitoring occur in villages with larger family lineage clans and these factors contribute to a reduction in the average incidence of land reallocation, then the relationship between the timing of elections and the timing of land reallocations, will likely exhibit different patterns across villages with different shares of residents in the main lineage group. As in Figure 2 (shown earlier) when the sample is stratified into two groups based on whether $60 \%$ or more of the households are in the largest lineage group, we see that homogenous villages have less incidence of land reallocation before or during election years, and are more likely to support reallocations in the period after (or alternatively, two years before) an election.

Differences in timing of reallocations relative to election timing in more and less homogenous villages is consistent with improved use of elections to monitor leaders through competitive elections in more homogenous villages. In particular, a village leader in a more homogenous village may be less likely to initiate a reallocation if he (or she) is more at risk of losing an election should one occur in the

\footnotetext{
${ }^{22}$ By law, the village assembly supervises the work of the village committee (see article 18 of the 1998 Organic Law for Village Committees) and can be convened with a simple majority participation of the villagers at or above the age of 18 or with the participation of the representatives from at least two-thirds of the households in the village. As a form of direct democracy, the village assembly is an unwieldy governing institution, especially in villages with large populations. In practice, the majority of villages ( $93 \%$ in our sample) adopt a more manageable village representative assembly instead. The real power of village (representative) assembly is questionable, however, given its infrequent meetings and its tendency to be controlled by village cadres (Oi and Rozelle, 2000).
} 
current or following year. To evaluate the possibility that village leaders face the threat of sanction, we examine how incumbent loss in village-wide elections varies with the timing of land reallocations (relative to the election) and how the effects of reallocation timing may vary with share of village in the largest lineage group and deaths per hundred village residents. Specifically we estimate model (14) below:

$$
\begin{aligned}
I L_{j t}=\alpha_{1} R_{j t}+ & \alpha_{2} R_{j t-1}+\alpha_{3} F_{j 0}+\alpha_{4} D_{j t}+\alpha_{5}\left(R_{j t} \times F_{j 0}\right)+\alpha_{6}\left(R_{j t-1} \times F_{j 0}\right) \\
& +\alpha_{6}\left(R_{j t} \times D_{j t}\right)+\alpha_{6}\left(R_{j t-1} \times D_{j t}\right)+\boldsymbol{Z}_{j 95}^{\prime} \boldsymbol{\beta}+\boldsymbol{X}^{\prime}{ }_{j 95} \boldsymbol{\gamma}+\mu_{j t}
\end{aligned}
$$

where $I L_{j t}$ is an indicator for whether an incumbent lost an election in village $j$ of year $t$. In alternate regression models, we add additional village level controls as of the first 1995 survey wave $\left(\boldsymbol{Z}_{j 95}\right)$, and then characteristics of the initial village leader $\left(\boldsymbol{X}_{\boldsymbol{j} 95}\right)$. Correlations with incumbent loss of an election are reported in Table 4, and cover 99 contested elections in which an incumbent village leader ran for reelection over the 1995 to 2003 period.

When land reallocation took place in the year before an election, the probability of incumbent loss increases by nearly 5 percent. Further, from the coefficients on the election-timing-largest lineage group variables, we note (in column 1), that the probability of losing an election is higher when a reallocation takes place in a more homogenous village. The effect of land reallocation is somewhat offset, however, if there have been more deaths in the village over the year, corresponding to a setting in which more residents are likely to view a reallocation to be necessary. We don't want to ascribe a causal interpretation to these models, but use them to underscore the plausibility that, depending on the size of the main lineage group and demographic changes in the village, reallocation decisions of village leaders are more or less associated with loss of an election. Significance levels decline on some 
interaction terms when including additional village and incumbent head characteristics (columns 2 and 3), but the essential relationship does not change.

The relationship between reallocation and subsequent election performance highlights the potential influence of election-timing, the number of deaths and the relative size of a main lineage group on the likelihood of significant future village-wide land reallocations. In recognition that these village level variables may have direct influence on migration through other channels, we control for their direct effects. For example, there may be less out-migration in an election year, or year before an election, if year-long presence allows residents to influence the dynamics of an election campaign or the selection of candidates. ${ }^{23}$ Further, as children's migration decisions may be related to the health and the death of parents (Giles and $\mathrm{Mu}, 2007$ ), the number of deaths may be associated with some out-migration from the village, particularly if deaths are related to agro-climatic or economic shocks. Finally, family lineage may also affect migration decisions through effects on social network effects important for migration, or through improved access to informal credit. To account for these concerns, the election timing dummies $G\left(E_{j t}\right)$ and number of deaths per hundred residents are directly included in the main regression, and the initial share of the village in the main lineage group, $F_{j 0}$, is absorbed in the village fixed effect. The effect of uncertainty over land reallocation is then identified off two sets of interactions with election timing dummy variables: interactions with number of deaths per hundred residents $\left(D_{j t} \times G\left(E_{j t}\right)\right)$, and with initial year share of village households in the main lineage group $\left(F_{j 0} \times G\left(E_{j t}\right)\right)$.

Crucial for our identification strategy are two assumptions: (1) the likelihood that interactions of election timing variables with both initial size of the main patrilineal groups and deaths in the village influence the timing of land reallocation decisions; and (2) that these interactions do not have a direct effect on migration decisions independently of their influence on land reallocation. With respect to the

\footnotetext{
${ }^{23} \mathrm{As}$ a sizable share of the village migrant population will return during Spring Festival (Chinese New Year) celebrations, being a migrant does not preclude casting an election ballot. In addition, most villages have provisions under which an absent village resident may entrust a family member to cast his, or her, ballot.
} 
interaction of deaths in the village and election year timing, the withdrawal from agriculture of laborers who have died opens up a possibility for reallocation that is consistent with the standard demographic rule that is generally viewed as appropriate by village residents. The deaths-election-timing interaction thus picks up variation across villages, driven by differences in demographic change, in how residents interpret the relationship between election timing and a future reallocation.

The lineage group share - election-timing interaction terms exploit the institutional complementarity between elections in more and less homogenous villages and land reallocation to identify differences across villages in how the time to the next election forms expectations over the possibility of a future land reallocation. For these interaction terms to be valid instruments their joint effect must be independent of $\Delta \varepsilon_{i j t}$ in equation (11), which requires that the interaction terms are not systematically related to other time-varying factors associated with the productivity of farming, employment in the local economy or the net returns to migrating. Given the possibility that proximity to an election may be systematically related to public goods investments, over which the village leader may have control, and that such investments may be compliments to returns to farming or local activities, we thus examine directly whether our four interaction terms are associated with the timing of investments in local public goods. In Table 5, we show results from estimating regression models in which the four interaction instruments for change in significant reallocation, the village level exogenous regressors and province-year dummy variables conditional on village fixed effects from model 11 are regressed on changes in a range of annual public goods investments, including: total public investment (log); total number of projects; roads and bridges; drainage; irrigation; land infrastructure; protective forests; and environment and sanitation improvements. ${ }^{24}$ Lack of correlation between interactions with electiontiming dummy variables and changes in other public goods investments suggests that the relationship

\footnotetext{
${ }^{24}$ The history of specific public goods investments is enumerated Table F4 of the Supplemental 2004 Village Governance Survey.
} 
between our instruments and future land reallocation risk is not contaminated by other decisions of village leaders that may affect individual decisions over productive investments or migration.

\section{Future Land Reallocations and the Decision to Migrate}

As a starting point in examining effects of land tenure insecurity on current migration decisions, we first examine results from the OLS and first-differenced models in Table 6. Both models include the full set of individual, household and village-level variables discussed in our estimation strategy. In the OLS specification, the coefficient on future land reallocation is -0.016 and statistically significant. Given that 16 percent of 16 to 50 year olds, on average, worked as migrants during the period, this amounts to a ten percent reduction in the probability of migrating. Gender- and age-time trends carry expected signs and are consistent with other descriptive work, and in OLS models the probability of being a migrant is positively associated with educational attainment. An individual is also more likely to migrate if the working-age share of household registered residents (exclusive of the individual himself, or herself) is greater, which is consistent with the likelihood that the marginal product of adult labor on household land will be lower in households with more family members.

The likely presence of important time-varying unobservables is underscored by positive coefficients on village land per capita and the time-varying village land gini index. If average land quality and offfarm opportunities were the same, after controlling for village fixed effects, we would expect to observe a negative sign village land per capita. In fact, land per capita may be increasing more rapidly, with more permanent migration or in less dynamic regions with fewer local opportunities. This unobserved difference across villages is consistent with a positive coefficient on village land per capita. With respect to the village land per capita gini, one might expect to see a negative sign if increases in land inequality predicted a future land reallocation. In fact, the considerable heterogeneity in governance of land and in ability to formally rent land to other households makes it likely that, in some villages, longer-term 
increases in the village land per capita gini are associated with increases in security of land tenure. As the land per capita gini may reflect, in part, unmeasured perceptions of the security of tenure, it is not surprising to find a significant positive coefficient on this regressor in OLS models.

Once controlling for some aspects of unobserved heterogeneity in the first-differenced implementation, shown in the second column of Table 6 , the coefficient on change in future land reallocation decreases in magnitude to -0.005 and is only marginally significant. Economically, this coefficient suggests only a 3.1 percent decrease in migration due to insecure property rights. As discussed above, however, biases due to time-varying unobserved heterogeneity related to economic shocks or other changes may yet be biasing the coefficient on future land reallocations to zero. Further, one consequence of differencing is an increase in classical measurement error bias, which also biases the coefficient on future land reallocation toward zero.

Apart from the coefficient on future land reallocations, other coefficients in the first-differenced models are consistent with some reduction in biases from unobserved heterogeneity. Specifically, coefficients on time-varying village-wide land measures (village land per capita and the village land gini) are now small in magnitude and not significantly different from zero. The negative coefficients on change in male and female adult shares in the household suggest that the probability that an individual chooses to migrate may decline when there are improved opportunities in the local community (which also could be correlated with growth in long-term household members).

We turn to the instrumental variable results in Table 7. Results from the first stage, shown in the first column, suggest that the interaction instruments perform reasonably well at predicting future land reallocations. In more homogenous villages, a future land reallocation is less likely if the current year is the year before a regularly scheduled election. This is consistent with our earlier finding that village leaders are less likely to survive an election if they implement a reallocation in an election year. In villages that have experienced more deaths per hundred in the current year, by contrast, residents are 
more likely to experience a reallocation in the following year if the current year is the year of, or one year before, a regularly scheduled election. Apart from the instruments, it is also of interest to note that increases in village average income growth are negatively associated with a future reallocation, which is consistent with a view that village heads are frequently motivated to redistribute land to improve overall village efficiency. If village income is already growing, there may be less obvious scope for increasing incomes by transferring land to landless households. There is evidence from the coefficient on change in land per capita that there is an increase in the likelihood that village leaders will also initiate an administrative reallocation.

Turning to the second stage, we observe an economically and statistically significant association between an increase in probability of a future land reallocation and the likelihood that an individual will work as a migrant. The coefficient on the future land reallocation variable suggests that a registered resident will be 2.8 percent less likely to migrate if he (or she) expects a significant land reallocation in the following year. Given that an average of 16 percent of 16 to 50 year olds worked as migrants during this period, this amounts to $17.5 \%$ of the annual migration share during the period, suggesting that risk of administrative reallocation is an important factor in the migration decision.

As one might be concerned that household demographic changes may be endogenous, we next estimate models excluding household characteristics. This reduces the likelihood that unobserved shocks affecting household composition are also influencing individual migration decisions and biasing our results. Excluding household level variables (household demographic composition, landing holding and consumption) in Table 8, the estimated coefficient on significant future land reallocation remains nearly the same at -2.7 percent (column 2, Table 8). Over-identification tests reported in both Tables 7 and 8 suggest that there is no direct statistical evidence against the validity of the interaction-term instruments. 
In examining the regression statistics, one should have some concern over the possibility of weak instrument bias. With a cluster-robust Angrist-Pischke F-statistic of 4 in our preferred model, and a pvalue 0.007 , one might be concerned that the first-stage is not sufficiently strong. Standard rules of thumb for weak instruments (e.g., Stock and Yogo, 2005) suggest that when first stage instruments have an F-statistic below 10, there is considerable risk of weak instrument bias. This rule of thumb, however, is based on non-clustered cases with independently and identically standard errors, and may not always be appropriate for when there are systematic relationships among standard errors and cluster-corrected F-statistics are used to assess instrument strength (Cameron and Miller, 2011; Cameron and Miller, 2013). We thus implement a version of Moreira's (2003) conditional likelihood ratio (CLR) test proposed by Finlay and Magnusson (2009) to test for robustness to weak instrument bias with standard errors clustered at the village level. ${ }^{25}$ Using both the clustered CLR test, and the Anderson-Rubin test (which is somewhat weaker), we estimate $95 \%$ confidence intervals around the coefficient on future village land reallocation. Results from both tests, provided at the bottom of Tables 7 and 8 , suggest that the negative association between expected land reallocation activity and future migration is significant.

\section{Conclusions}

Through the early 2000s, farmers in rural China faced substantial risk of losing land in large scale village-wide land reallocations. The present paper exploits that fact that land reallocation decisions appear to be strategically decided by village cadres who take the timing of village elections into consideration, and that the specific timing of these decisions are influenced by underlying features of village political economy. Specifically, village leaders in more homogenous villages face greater risk of losing an election in the year of, or year following, a reallocation, and thus they may devote less effort to

\footnotetext{
${ }^{25}$ This extension of Moreira (2003) uses a GMM minimum distance estimator to allow for clustered dependence and heteroskedasticity, and is an approach suggested by Cameron and Miller $(2011,2013)$ among others.
} 
land reallocation. We find that, in expectation of a land reallocation in the following year, rural residents reduced their propensity to migrate for work by 2.7 percent, or 17.5 percent of the annual migration rate, which provides evidence that insecure property rights shaped the movement of labor out of agriculture.

Even though some observers have argued that administrative land reallocation may promote equity and potentially improve land-labor matching in the absence of land market, any potential benefits associated with land reallocations may come with an additional efficiency loss. Our results suggest that strengthening property rights over agricultural land may be essential for removing biases in the movement of labor out of agriculture during the process of structural change and urbanization. As migration for work generally contributed to higher earnings and consumption of China's rural residents (de Brauw and Giles, 2008), one direction for future work on the effects of insecure property rights would be to examine the effects of insecure property rights on measures of income and well-being. As rural areas continue to depopulate with increases in the movement of labor to urban areas, one would expect that rural institutions, including those governing land, to change in response to migrationinduced social and demographic changes. More research is needed to examine potential relationships between migration and the evolution of property rights. Even as the Rural Land Contracting Law provided stronger claims to contracted land after 2003, land tenure insecurity is manifest in increased seizure of land without proper compensation, as opposed to reallocations of an earlier era. Reducing labor migration may not be an effective strategy for rural residents to prevent land seizures and they may have to undergo costly adjustment to labor allocation to cope with land loss. More research is needed to examine how rural residents cope with this new source of insecurity and the institutional arrangements that may reduce the incidences of such land-taking. 


\section{References}

Acemoglu, Daron, Johnson, Simon, and Robinson, James. 2001. "The Colonial Origins of Comparative Development: An Empirical Investigation." American Economic Review 91(5): 1369-1401.

Au, Chun-Chung, and Henderson, J. Vernon. 2006. "How Migration Restriction Limit Agglomeration and Productivity in China." Journal of Development Economics, 80: 350-88.

Bandiera, Oriana. 2007. "Land Tenure, Investment Incentives, and the Choice of Techniques: Evidence from Nicaragua." The World Bank Economic Review, 21(3): 487-508.

Benjamin, Dwayne and Loren Brandt. 2002. "Property Rights, Labour Markets, and Efficiency in a Transition Economy: The Case of Rural China," Canadian Journal of Economics, 35(4): 689-716.

Benjamin, Dwayne, Loren Brandt and John Giles. 2005. "The Evolution of Inequality in Rural China," Economic Development and Cultural Change, 53(4) (July 2005): 769-824.

Besley, Timothy. 1995. "Property Rights and Investment Incentives: Theory and Evidence from Ghana," Journal of Political Economy, 103(5): 903-37.

Besley, Timothy, and Ghatak, Maitreesh. 2009a. "The de Soto Effect." Center for Economic Policy Research Discussion Paper 008.

Besley, Timothy, and Ghatak, Maitreesh. 2009b. “Property Rights and Economic Development." Center for Economic Policy Research Discussion Paper 7234.

Brandt, Loren, Rozelle, Scott, and Turner, Matthew. 2004. "Local Government Behavior and Property Right Formation in Rural China." Journal of Institutional and Theoretical Economics, 160(4): 627-49.

Brasselle, A-S., Gaspart, F., Platteau, J-P. 2002. "Land Tenure Security and Investment Incentives: Puzzling Evidence from Burkina Faso," Journal of Development Economics, 67: 373-41.

Cai, Fang, Wang, Dewen and Du, Yang. 2002 "Regional Disparity and Economic Growth in China, the Impact of Labor Market Distortions" China Economic Review 13: 197-212.

Cameron, Colin A. and Douglas L. Miller. 2011. "Robust Inference with Clustered Data," in A. Ullah and D.E. Giles eds., Handbook of Empirical Economics and Finance, CRC Press.

Cameron, Colin A. and Douglas L. Miller. 2013. " A Practitioner's Guide to Cluster-Robust Inference," Journal of Human Resources (in press).

CRLSRT (China Rural Local Self-governance Research Team). 2000. Study on China's rural self-governance. [In Chinese]. Beijing: China Agriculture Publishing House.

de Brauw, Alan, and Mueller, Valerie. 2012. "Do Limitations in Land Rights Transferability Influence Low Mobility Rates in Ethiopia?" Journal of African Economies, 21(4) (August): 548-79. 
de Brauw, Alan, and Giles, John. 2008. "Rural to Urban Migration in China: How Do Migrant-Sending Communities Benefit?” World Bank Policy Research Working Paper 4585.

Deininger, Klaus, and Jin, Songqing. 2009. "Securing Property Rights in Transition: Lessons from Implementation of China's Rural Land Contracting Law." Journal of Economic Behavior and Organization, 70(1-2), 22-38.

de Meza, David, and Gould, J. R. 1992. "The Social Efficiency of Private Decisions to Enforce Property Rights." Journal of Political Economy 100(3):561-80.

Do, Quy-Toan, and lyer, Lakshmi. 2008. "Land Titling and Rural Transition in Vietnam." Economic Development and Cultural Change 56(3): 531-79.

Fan, Cindy. 2008. "Migration, Hukou and the City." in Shahid Yusuf and Karen Nabeshima, eds. China Urbanizes: Consequences, Strategies, and Policies Washington, D.C.: The World Bank.

Feder, Gershon, and Feeny, David. 1991. "Land Tenure and Property Rights: Theory and Implications for Development Policy." The World Bank Economic Review 5(1): 135-53.

Field, Erica. 2005. "Property Rights and Investment in Urban Slums." Journal of the European Economic Association 3(2-3): 279-90.

Field, Erica. 2007. "Entitled to Work: Urban Tenure Security and Labor Supply in Peru." Quarterly Journal of Economics 4(122): 1561-1602.

Finlay, Keith and Leandro Magnusson. 2009. "'Implementing Weak-Instrument Robust Tests for a General Class of Instrumental-Variables Models," Stata Journal, 9(3): 398-421.

Galiani, Sebstian and Schargrodsky, Ernesto. 2005 "Property Rights for the Poor: Effects of Land Titling." Universidad Torcuato Di Tella, Business School Working Paper No. 06/2005.

Giles, John. 2001. "Risk, Shock and Weak Property Rights in the Labor Allocation Decision of Rural Chinese Households," paper presented at 2000 Meetings of the Northeast Universities Development Economics Consortium, Cornell, October 2000.

Giles, John. 2006. "Is Life More Risky in the Open? Household Risk-Coping and the Opening of China's Labor Markets." Journal of Development Economics 81(1): 25-60.

Goldstein, Markus, and Udry, Christopher. 2008. "The Profits of Power: Land Rights and Agricultural Investment in Ghana." Journal of Political Economy 116(6): 981-1022.

Harris, J., Todaro, M., 1970. Migration, unemployment, and development: a two-sector analysis. American Economic Review 60 (1), 126-142.

Jacoby, Hanan, Li, Guo, and Rozelle, Scott. 2002. "Hazards of Expropriation: Tenure Insecurity and Investment in Rural China." American Economic Review 92(5): 1420-47. 
Katz, Barbara, and Owen, Joel. 2009. “Are Property Rights Enough? Re-evaluating a Big-Bang Claim.” Economics of Transition 17(1): 75-96.

Kung, J.K., 1995. Equal entitlement versus tenure security under a regime of collective property rights: peasants' preference for institutions in post-reform Chinese agriculture." Journal of Comparative Economics, 21(1), pp. 82-111.

Kung, J.K. 2000. "Common property rights and land reallocations in rural China: evidence from a village survey." World Development, 28(4), pp. 701-719.

Kuznets, Simon. 1955. "Economic Growth and Income Inequality," American Economic Review, 45(1): 128.

Lewis, W. Arthur. 1954. "Development with Unlimited Supplies of Labour," The Manchester School, May 1954, 22: 139-92.

Lewis, W. Arthur. 1958. "Unlimited Labour: Further Notes," The Manchester School, January 1958, 26:132.

Liu, S., Carter, M.C. and Yao, Y. 1998. "Dimensions and diversity of property rights in rural China: dilemmas on the road to further reform." World Development, 26(10), pp. 1789-1806.

Liu, Zhiqiang 2005. "Institution and inequality: the hukou system in China." Journal of Comparative Economics 33: 133-57.

Lohmar, Bryan. 2000. "The Effects of Land Tenure and Grain Quota Policies on Farm Household Labor Allocation in China," PhD Dissertation, Department of Agriculture and Resource Economics, University of California at Davis.

Martinez-Bravo, Monica, Gerard Padró i Miquel, Nancy Qian and Yang Yao. 2014. "Political Reform in China: The Effect of Local Elections," Yale University, mimeo (July 16, 2014).

Mu, Ren and Zhang, Xiaobo. 2014."Do Elected Leaders in a Limited Democracy Have Real Power? Evidence from Rural China," Journal of Development Economics 107: 17-27.

Mullan, Katrina, Grosejean, Pauline, and Kontoleon, Andreas. 2011. "Land Tenure Arrangement and Rural-Urban Migration in China," World Development 39(1): 123-33.

North, Douglass. 1990. Institutions, Institutional Change and Economic Performance. Cambridge: Cambridge University Press

O'Brien, K., Li, L., 2000. "Accommodating "democracy" in a one-party state: introducing village elections in China," China Quarterly 162: 465- 89. 
Oi, J., Rozelle, S., 2000. Elections and power: The locus of decision-making in Chinese villages. The China Quarterly 162, 513-539.

Park, Albert. 2008. "Rural-Urban Inequality in China," in Shahid Yusuf and Karen Nabeshima, eds. China Urbanizes: Consequences, Strategies, and Policies Washington, D.C.: The World Bank.

Ranis, Gustav and John C. H. Fei. 1961. "A Theory of Economic Development," The American Economic Review, 51(4): 533-565.

Ravallion, Martin and Shaohua Chen. 2007. "China's (Uneven) Progress Against Poverty," Journal of Development Economics, 82(1) (January): 1-42.

Rozelle, Scott and Guo Li. 1998. "Village Leaders and Land-Rights Formation in China," American Economic Review 88(2): 433-38.

Rozenzweig, Mark and Oded Stark. 1989. “Consumption Smoothing, Migration, and Marriage: Evidence from Rural India," Journal of Political Economy, 97 (4) (August): 905-926.

Sánchez, Fabio, López-uribe, María del Pilar, and Fazio, Antonella. 2010. "Land Conflicts, Property Rights, and the Rise of the Export Economy in Colombia, 1850-1925." Journal of Economic History 70(2): 378-399.

Tang, Ming. 2004. Legal Issues in the Elections of Villagers' Committees [in Chinese] Beijing: The Publishing House of the Chinese Academy of Social Science.

Tsai, Lily. 2007. "Solidarity Groups, Informal Accountability, and Local Public Goods Provision in Rural China." American Political Science Review 101(2): 355-72.

Valsecchi, Michele. 2010 "Land Certification and International Migration: Evidence from Mexico." Working Papers in Economics No. 440, University of Gothenburg.

Woodruff, Christopher and Rene Zenteno. 2007." Migration Networks and Microenterprises in Mexico," Journal of Development Economics, 82(2) (March): 509-28.

Xu, Yiqing and Yao, Yang. 2009 "Social Networks Enhance Grassroots Democracy: Surname Groups and Public Goods Provision in Rural China." CCER Working paper

Zhang, X., S. Fan, L. Zhang, and J. Huang. 2004. "Local governance and public goods provision in rural China." Journal of Public Economics 88 (12): 2857-2871. 
Table 1. The Incidence of Significant Land Reallocation and Share of Households Affected (1995-2003)

\begin{tabular}{lccccccccccc}
\hline & All & $\mathbf{1 9 9 5}$ & $\mathbf{1 9 9 6}$ & $\mathbf{1 9 9 7}$ & $\mathbf{1 9 9 8}$ & $\mathbf{1 9 9 9}$ & $\mathbf{2 0 0 0}$ & $\mathbf{2 0 0 1}$ & $\mathbf{2 0 0 2}$ & $\mathbf{2 0 0 3}$ \\
\hline \multicolumn{7}{c}{ Panel A: Share of Villages } & Experiencing Significant Land Reallocation & & \\
All & 0.188 & 0.273 & 0.109 & 0.073 & 0.327 & 0.200 & 0.200 & 0.182 & 0.164 & 0.164 \\
Anhui & 0.167 & 0.556 & 0.222 & 0.000 & 0.056 & 0.167 & 0.222 & 0.111 & 0.056 & 0.111 \\
Henan & 0.181 & 0.188 & 0.000 & 0.063 & 0.438 & 0.188 & 0.250 & 0.250 & 0.125 & 0.125 \\
Jiangsu & 0.343 & 0.182 & 0.182 & 0.273 & 0.818 & 0.273 & 0.182 & 0.364 & 0.545 & 0.273 \\
Shanxi & 0.067 & 0.000 & 0.000 & 0.000 & 0.100 & 0.200 & 0.000 & 0.000 & 0.000 & 0.200 \\
Number of villages & 55 & 55 & 55 & 55 & 55 & 55 & 55 & 55 & 55 & 55 \\
& Panel B: Share of Households Affected in Significant Village Land Reallocations & & \\
All & 0.321 & 0.557 & 0.313 & 0.187 & 0.654 & 0.271 & 0.127 & 0.231 & 0.233 & 0.219 \\
Anhui & 0.319 & 0.648 & 0.472 & 0.000 & 0.676 & 0.348 & 0.110 & 0.121 & 0.276 & 0.180 \\
Henan & 0.282 & 0.596 & 0.000 & 0.478 & 0.798 & 0.282 & 0.101 & 0.293 & 0.224 & 0.125 \\
Jiangsu & 0.358 & 0.010 & 0.070 & 0.092 & 0.522 & 0.037 & 0.336 & 0.219 & 0.232 & 0.245 \\
Shanxi & 0.349 & 0.000 & 0.000 & 0.000 & 0.808 & 0.474 & 0.000 & 0.000 & 0.000 & 0.279 \\
Number of households & 1858 & 799 & 291 & 273 & 947 & 722 & 796 & 536 & 520 & 581 \\
\hline
\end{tabular}

Note: Shares in Panel B are calculated conditional on the village experiencing a significant land reallocation during the year.

Source: 2004 Village Governance Survey and Land Use Survey, RCRE, Ministry of Agriculture. 
Table 2. Share of Villages with a Regularly Scheduled Election

\begin{tabular}{lcccccccccc}
\hline & All & $\mathbf{1 9 9 5}$ & $\mathbf{1 9 9 6}$ & $\mathbf{1 9 9 7}$ & $\mathbf{1 9 9 8}$ & $\mathbf{1 9 9 9}$ & $\mathbf{2 0 0 0}$ & $\mathbf{2 0 0 1}$ & $\mathbf{2 0 0 2}$ & $\mathbf{2 0 0 3}$ \\
\hline All & 0.154 & 0.145 & 0.145 & 0.182 & 0.182 & 0.182 & 0.091 & 0.182 & 0.182 & 0.091 \\
Anhui & 0.123 & 0.111 & 0.111 & 0.222 & 0.056 & 0.278 & 0.056 & 0.167 & 0.111 & 0 \\
Henan & 0.139 & 0.125 & 0.125 & 0.125 & 0.125 & 0.25 & 0.063 & 0.125 & 0.25 & 0.063 \\
Jiangsu & 0.222 & 0.273 & 0.182 & 0.091 & 0.455 & 0.091 & 0.182 & 0.364 & 0.182 & 0.182 \\
Shanxi & 0.156 & 0.1 & 0.2 & 0.3 & 0.2 & 0 & 0.1 & 0.1 & 0.2 & 0.2 \\
\hline Number of villages & 55 & 55 & 55 & 55 & 55 & 55 & 55 & 55 & 55 & 55 \\
\hline
\end{tabular}

Source: 2004 Village Governance Survey and Land Use Survey, RCRE, Ministry of Agriculture. 
Table 3. Share of Laborers (Age 16-50) Migrating for Work Outside the Home County (1995-2002)

\begin{tabular}{|c|c|c|c|c|c|c|c|c|c|}
\hline & All & 1995 & 1996 & 1997 & 1998 & 1999 & 2000 & 2001 & 2002 \\
\hline All & 0.158 & 0.088 & 0.098 & 0.110 & 0.144 & 0.155 & 0.182 & 0.219 & 0.265 \\
\hline Men & 0.204 & 0.121 & 0.134 & 0.146 & 0.188 & 0.202 & 0.232 & 0.28 & 0.332 \\
\hline Women & 0.110 & 0.052 & 0.06 & 0.072 & 0.097 & 0.106 & 0.132 & 0.159 & 0.197 \\
\hline Age 16-29 & 0.203 & 0.114 & 0.126 & 0.142 & 0.179 & 0.200 & 0.237 & 0.292 & 0.353 \\
\hline Age 30-50 & 0.107 & 0.058 & 0.065 & 0.070 & 0.100 & 0.103 & 0.121 & 0.146 & 0.180 \\
\hline Less than 8 years of schooling & 0.100 & 0.054 & 0.06 & 0.068 & 0.094 & 0.100 & 0.116 & 0.144 & 0.180 \\
\hline Eight or more years of schooling & 0.200 & 0.118 & 0.129 & 0.142 & 0.181 & 0.193 & 0.229 & 0.268 & 0.319 \\
\hline A member of the largest patrilineal clan in village & 0.159 & 0.085 & 0.105 & 0.116 & 0.140 & 0.173 & 0.172 & 0.208 & 0.263 \\
\hline Not a member of the largest patrilineal clan in village & 0.157 & 0.089 & 0.096 & 0.108 & 0.145 & 0.148 & 0.186 & 0.223 & 0.266 \\
\hline With young women (age 19-24) or men (age 21-26) in household & 0.163 & 0.105 & 0.108 & 0.115 & 0.155 & 0.16 & 0.184 & 0.214 & 0.261 \\
\hline Without young women or men in household & 0.153 & 0.075 & 0.091 & 0.105 & 0.134 & 0.15 & 0.181 & 0.223 & 0.268 \\
\hline Obs. & 56342 & 6705 & 7138 & 7395 & 6650 & 7444 & 7072 & 6843 & 7095 \\
\hline
\end{tabular}

Source: 2004 Rural Household Social Network, Labor Allocation and Land Use Survey, RCRE, Ministry of Agriculture. 
Figure 1

Migration Rates by Age and Gender (1995-2003)

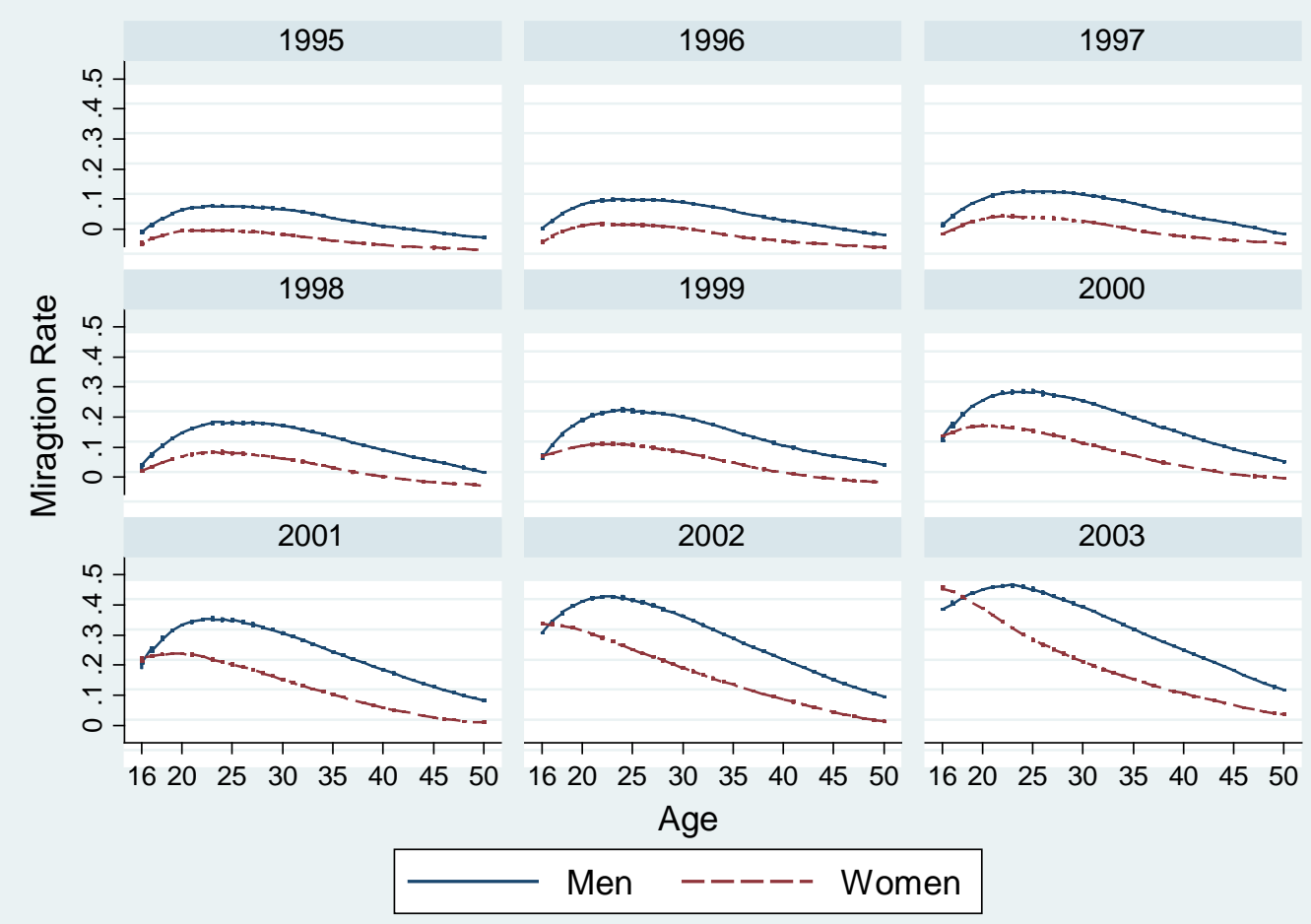

Source: 2004 Rural Household Social Network, Labor Allocation and Land Use Survey RCRE, Ministry of Agriculture). This supplemental survey conducted in August and September 2004 asked information about the age, gender, education and work and residence location history of all current and former household residents back to the 1995 wave of the matching RCRE Household Survey. 
Figure 2

\section{Election Timing and the Timing of Significant Land Reallocations}

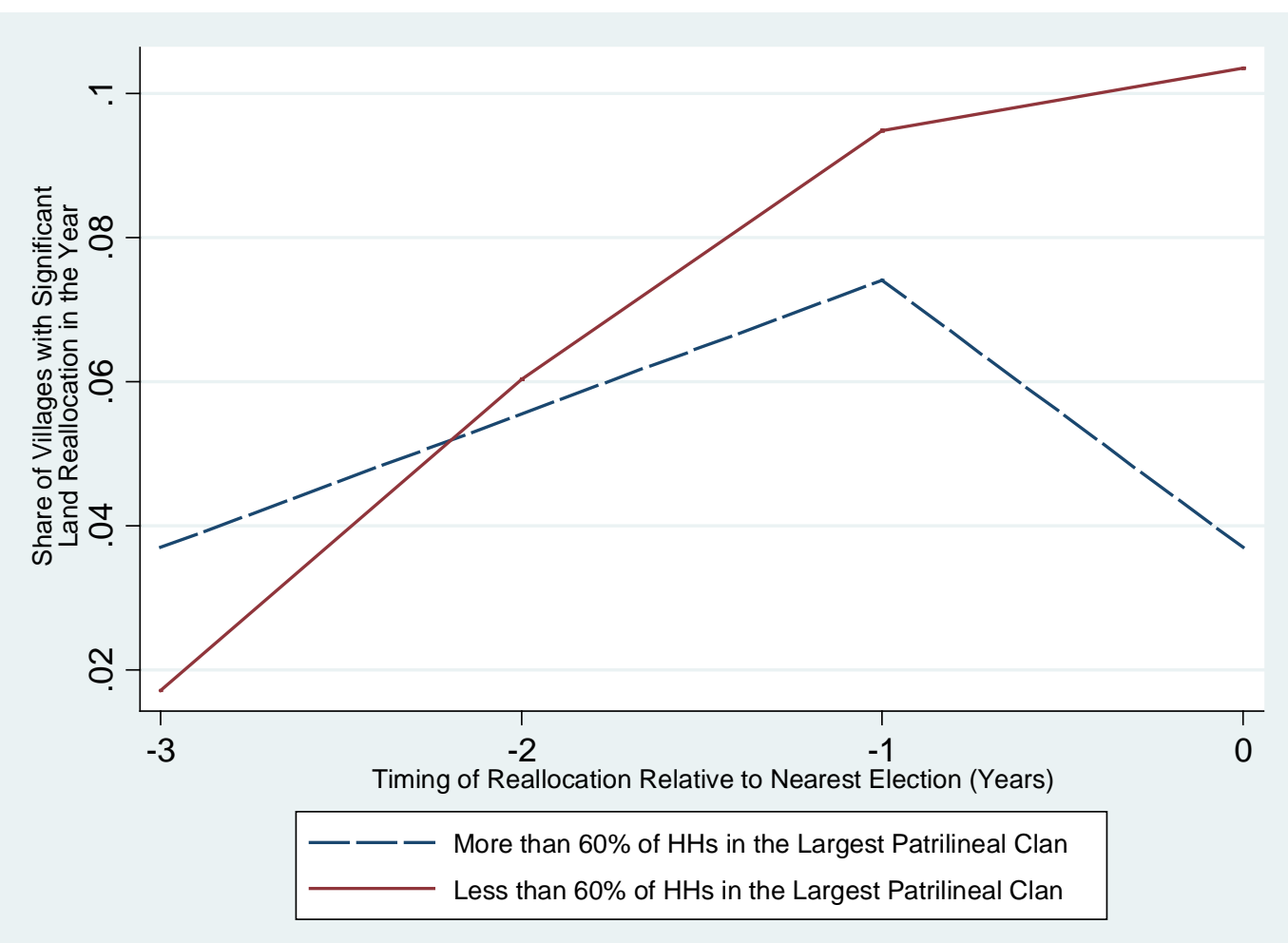

Source: RCRE Supplemental Village and Household Surveys (2004). Note that reallocations are considered to be significant if a village-wide reallocation is indicated on the village survey instrument, or if more than ten percent of households in the village indicate facing a reallocation. 


\section{Figure 3}

\section{Demographic Change and Probability of Land Reallocation}

(Deaths Per Hundred Versus Significant Land Reallocation)

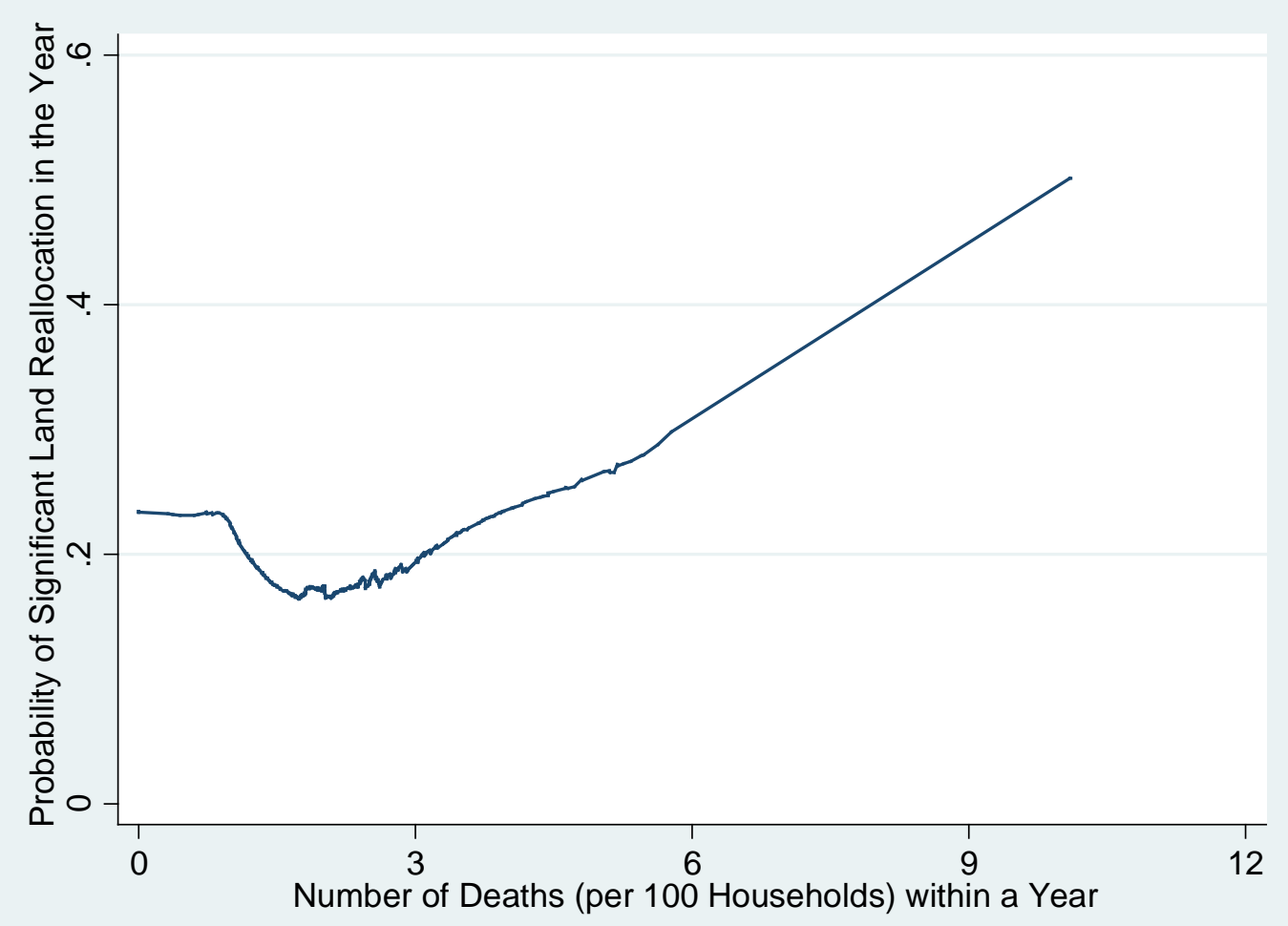

Source: RCRE Annual Village Surveys (1995-2003) and 2004 Rural Household Social Network, Labor Allocation and Land Use Survey, RCRE, Ministry of Agriculture.. 


\section{Figure 4}

Share of Households in the Largest Lineage Group (1995) and Probablity of Significant Land Reallcoation in the Village (1995-2003)

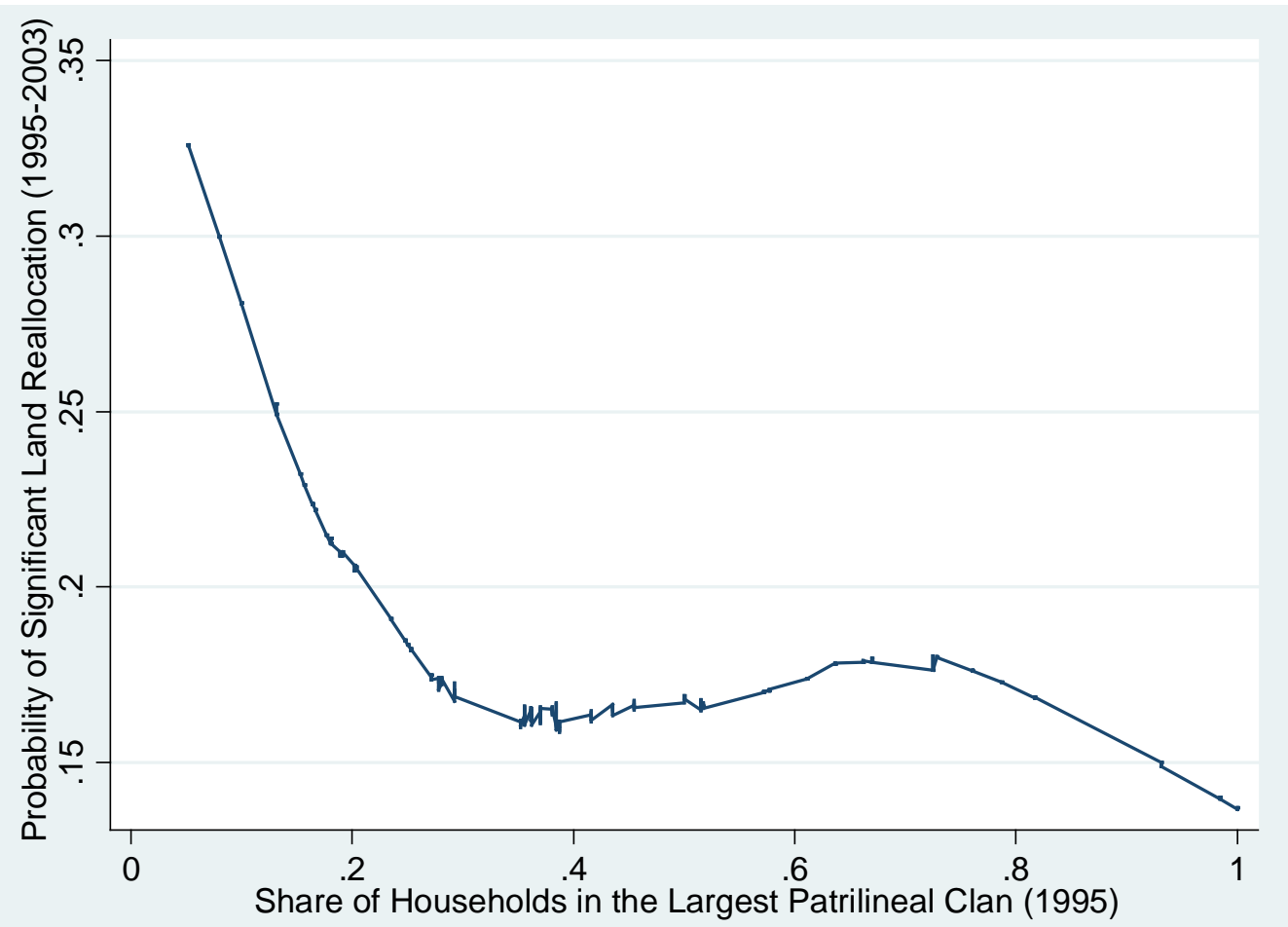

Source: 2004 Rural Household Social Network, Labor Allocation and Land Use Survey, RCRE, Ministry of Agriculture.

Note: the share of households in the largest family lineage group (patrilineal clan) is measured in 1995, which is the initial year of the analysis sample. 
Figure 5

Share of Households in the Largest Lineage Group (1995) and Numbers of Civil Disputes and Criminal Cases in 2003

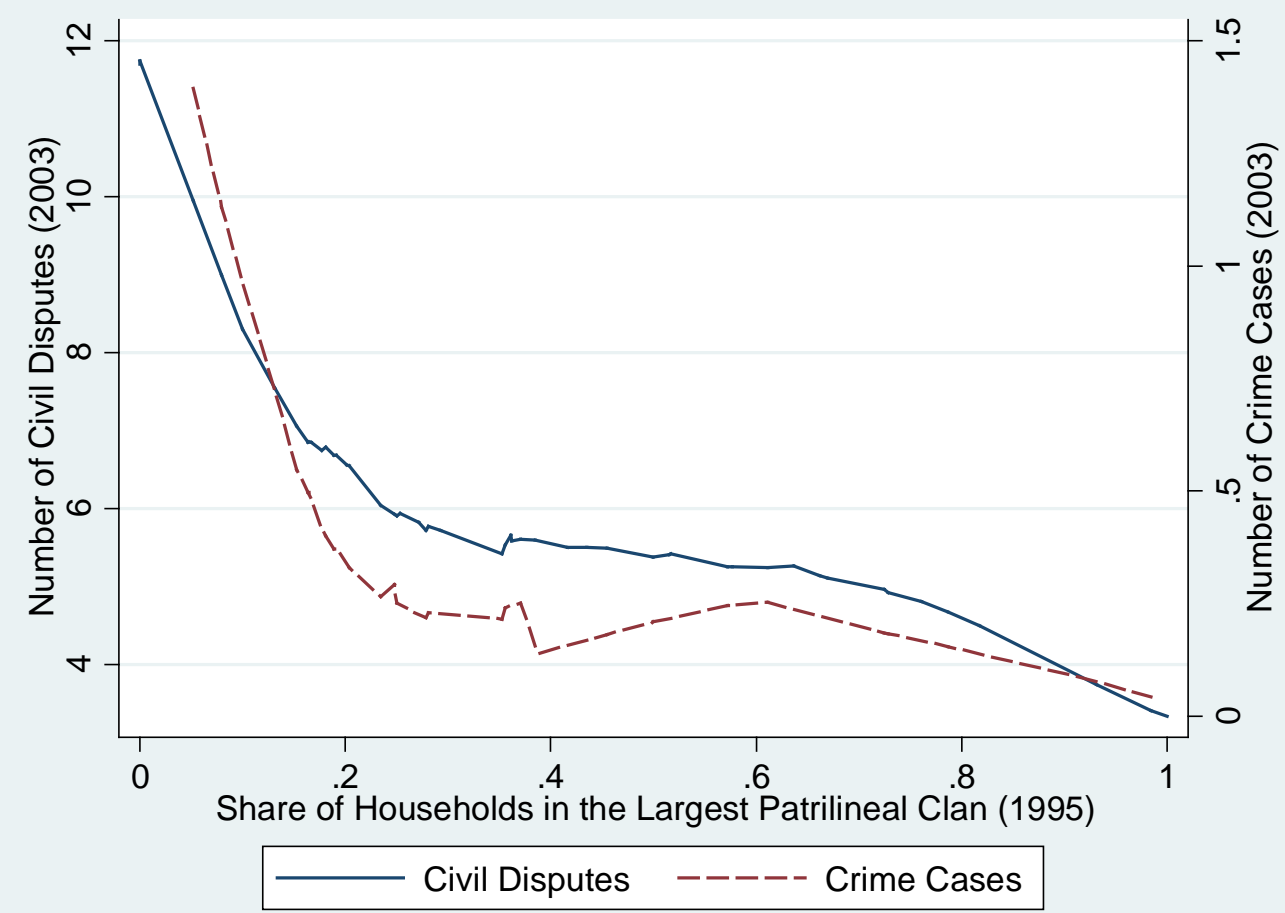

Source: 2004 Rural Household Social Network, Labor Allocation and Land Use Survey, RCRE, Ministry of Agriculture. 
Figure 6

Share of Households in Largest Lineage Group (1995), Disputes over Land as the Most Important Source of Conflict (2003), and Share of Households Participating in Land Rental(2003)

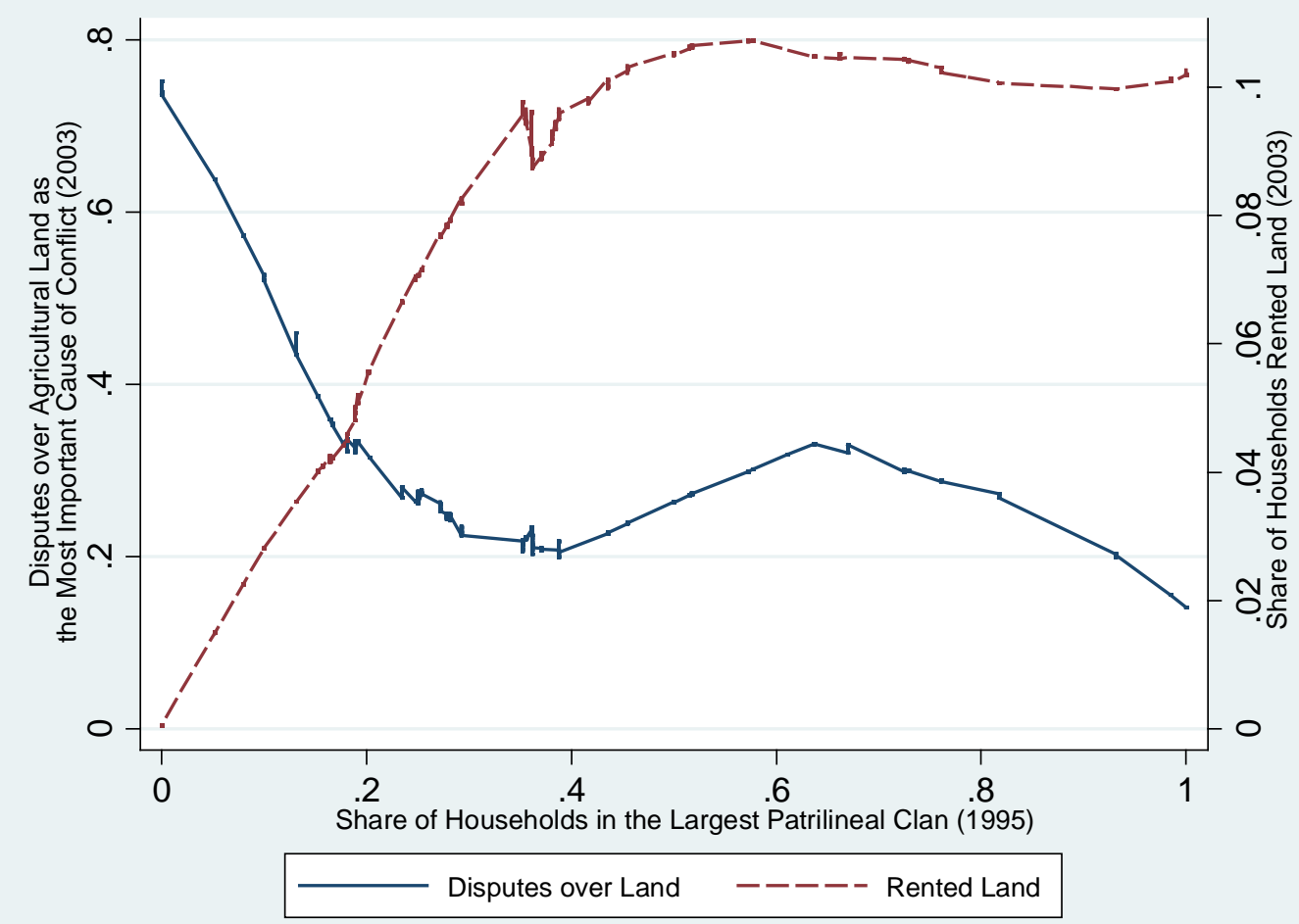

Source: 2004 Rural Household Social Network, Labor Allocation and Land Use Survey, and 2003 RCRE Village Survey, RCRE, Ministry of Agriculture. 
Figure 7

Share of Households in Largest Family Lineage Group (1995) and Responsibilities of the Village Representative Assembly

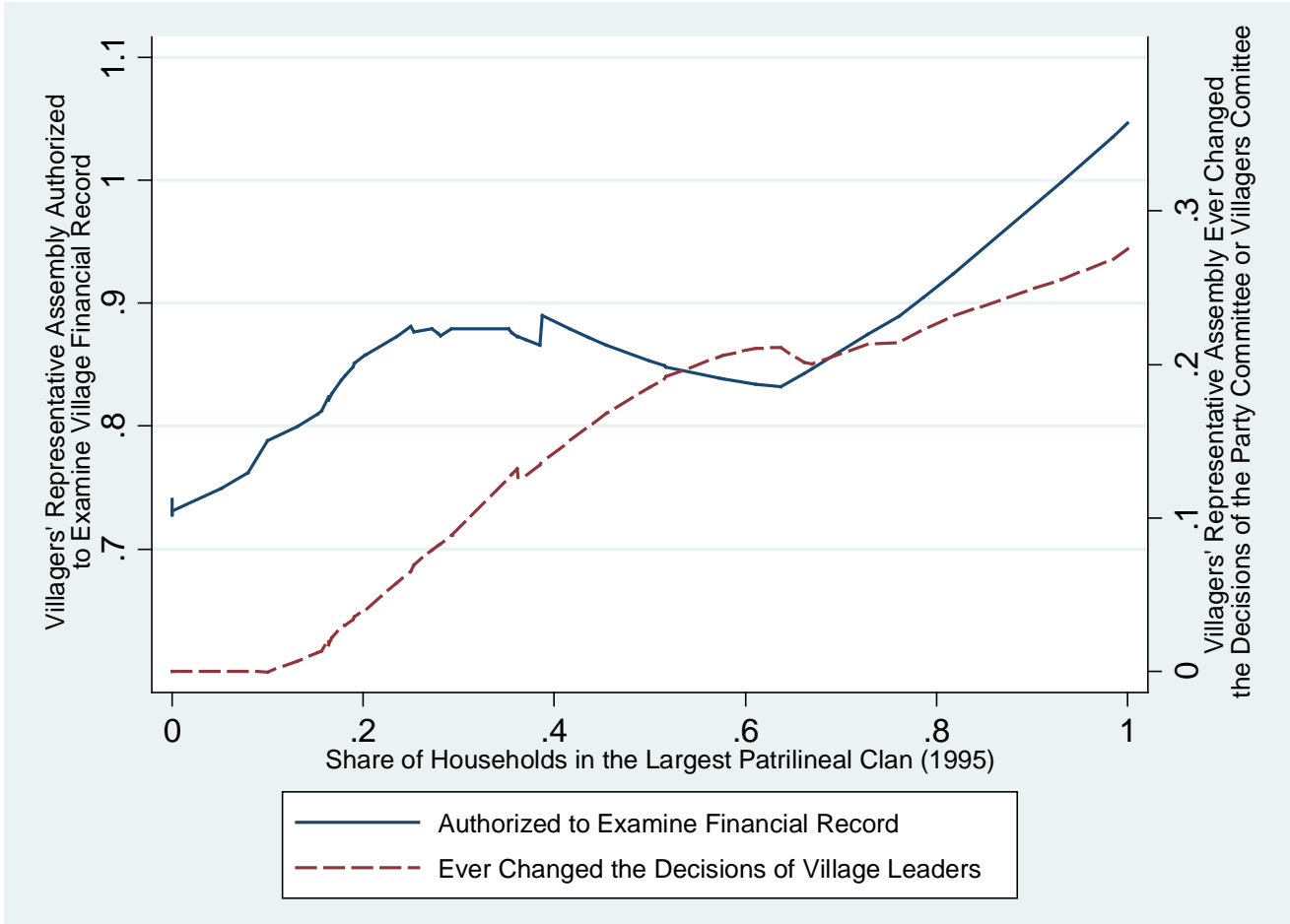

Source: 2004 Rural Household Social Network, Labor Allocation and Land Use Survey, RCRE, Ministry of Agriculture. 


\section{Figure 8}

Share of Households in Largest Lineage Group (1995) and

\section{Characteristics of the Most Recent Election}

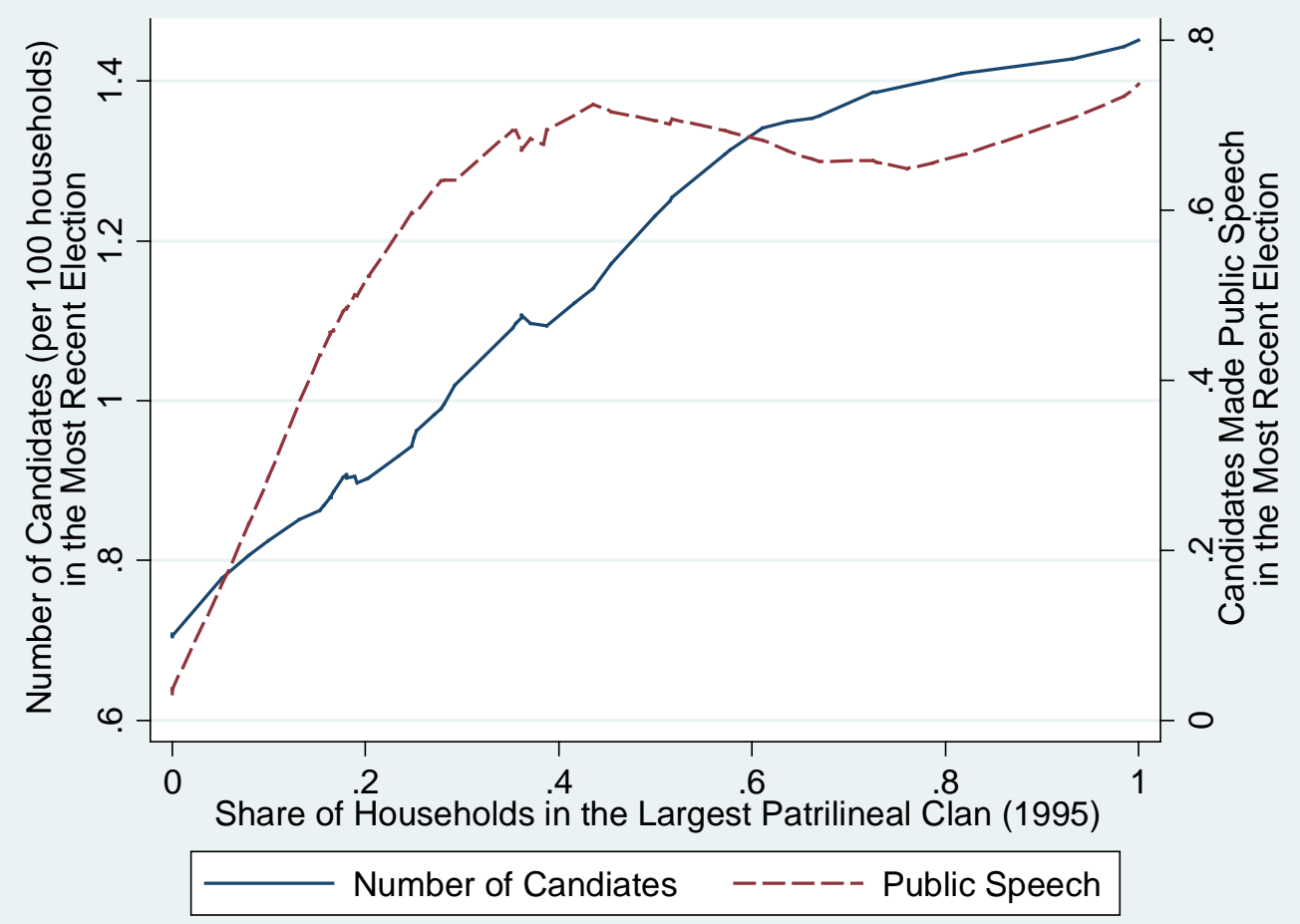

Source: 2004 Rural Household Social Network, Labor Allocation and Land Use Survey, RCRE, Ministry of Agriculture. 
Table 4. Land Reallocation Timing and the Probability that a Village Head will Lose an Election

\begin{tabular}{|c|c|c|c|}
\hline & (1) & (2) & (3) \\
\hline Land Reallocated in the Year of an Election & $\begin{array}{c}0.128 \\
(0.098)\end{array}$ & $\begin{array}{c}0.038 \\
(0.119)\end{array}$ & $\begin{array}{c}0.043 \\
(0.119)\end{array}$ \\
\hline Land Reallocated in Year Before an Election & $\begin{array}{c}0.053^{* * *} \\
(0.010)\end{array}$ & $\begin{array}{c}0.048^{* * *} \\
(0.012)\end{array}$ & $\begin{array}{c}0.051 * * * \\
(0.019)\end{array}$ \\
\hline Share of Households in the Largest Patrilineal Clan & $\begin{array}{c}0.211 \\
(0.230)\end{array}$ & $\begin{array}{l}-0.044 \\
(0.261)\end{array}$ & $\begin{array}{l}-0.089 \\
(0.281)\end{array}$ \\
\hline $\begin{array}{l}\text { Number of Deaths, Year Before Election } \\
\text { (per } 100 \text { households) }\end{array}$ & $\begin{array}{c}0.008 \\
(0.007)\end{array}$ & $\begin{array}{c}0.010 \\
(0.007)\end{array}$ & $\begin{array}{c}0.009 \\
(0.008)\end{array}$ \\
\hline $\begin{array}{l}\text { Share of Households in the Largest Patrilineal Clan } \\
\times \text { Land Reallocated in the Election Year }\end{array}$ & $\begin{array}{c}0.382 \\
(0.437)\end{array}$ & $\begin{array}{c}0.733 \\
(0.454)\end{array}$ & $\begin{array}{l}0.795^{*} \\
(0.470)\end{array}$ \\
\hline $\begin{array}{l}\text { Share of Households in the Largest Patrilineal Clan } \\
\times \text { Land Reallocated One Year Before the Election }\end{array}$ & $\begin{array}{c}0.089 * * * \\
(0.029)\end{array}$ & $\begin{array}{c}0.041 \\
(0.036)\end{array}$ & $\begin{array}{c}0.046 \\
(0.037)\end{array}$ \\
\hline $\begin{array}{l}\text { Number of Deaths within the Election Year (per } 100 \text { households) } \\
\times \text { Land Reallocated in the Election Year }\end{array}$ & $\begin{array}{l}-0.011 \\
(0.010)\end{array}$ & $\begin{array}{l}-0.015 \\
(0.011)\end{array}$ & $\begin{array}{l}-0.016 \\
(0.010)\end{array}$ \\
\hline $\begin{array}{l}\text { Number of Deaths in the Election Year (per } 100 \text { households) } \\
\times \text { Land Reallocated One Year Before the Ylection }\end{array}$ & $\begin{array}{c}-0.021^{* * *} \\
(0.007)\end{array}$ & $\begin{array}{c}-0.020^{* * *} \\
(0.007)\end{array}$ & $\begin{array}{c}-0.022^{* * *} \\
(0.008)\end{array}$ \\
\hline Village Population (log) in 1995 & & $\begin{array}{c}-0.269 * * \\
(0.106)\end{array}$ & $\begin{array}{c}-0.307^{* * *} \\
(0.116)\end{array}$ \\
\hline Village Income per Capita (log) in 1995 & & $\begin{array}{c}0.072 \\
(0.124)\end{array}$ & $\begin{array}{c}0.060 \\
(0.135)\end{array}$ \\
\hline Village Land per Capita (log) in 1995 & & $\begin{array}{c}0.002 \\
(0.061)\end{array}$ & $\begin{array}{l}-0.008 \\
(0.061)\end{array}$ \\
\hline Number of Village Cadres in 1995 & & $\begin{array}{c}0.009 \\
(0.019)\end{array}$ & $\begin{array}{c}0.003 \\
(0.021)\end{array}$ \\
\hline Share of Village Cadres with High School Education or Above in 1995 & & $\begin{array}{l}-0.378 \\
(0.342)\end{array}$ & $\begin{array}{l}-0.450 \\
(0.372)\end{array}$ \\
\hline Village Land Gini Index in 1995 & & $\begin{array}{c}1.285 \\
(1.100)\end{array}$ & $\begin{array}{c}1.549 \\
(1.042)\end{array}$ \\
\hline Years of Education Completed by the Incumbent & & & $\begin{array}{c}0.040 \\
(0.028)\end{array}$ \\
\hline Age of the Incumbent at Time of Assuming Position & & & $\begin{array}{c}0.005 \\
(0.006)\end{array}$ \\
\hline The Incumbent was Previously in the Army? & & & $\begin{array}{l}-0.049 \\
(0.160)\end{array}$ \\
\hline The Incumbent was a Party Member when Assuming the Position? & & & $\begin{array}{l}-0.016 \\
(0.151)\end{array}$ \\
\hline The Incumbent was a Member of a Major Patrilineal Clan & & & $\begin{array}{c}0.038 \\
(0.113)\end{array}$ \\
\hline $\begin{array}{l}\text { Constant } \\
\text { Province-specific year effects }\end{array}$ & $\begin{array}{c}0.216^{* *} \\
(0.092) \\
\text { included }\end{array}$ & $\begin{array}{c}1.425 \\
(1.222) \\
\text { included }\end{array}$ & $\begin{array}{c}1.271 \\
(1.211) \\
\text { included }\end{array}$ \\
\hline Number of observations & 99 & 99 & 99 \\
\hline
\end{tabular}




\section{Table 5. Public Goods Expenditures and Election Timing}

\begin{tabular}{|c|c|c|c|c|c|c|c|c|}
\hline & $\begin{array}{c}\Delta \text { Total } \\
\text { Public } \\
\text { Investment } \\
(\log ) \\
\end{array}$ & $\begin{array}{l}\Delta \text { Total } \\
\text { Number of } \\
\text { Projects }\end{array}$ & $\begin{array}{c}\Delta \text { Road or } \\
\text { Bridge }\end{array}$ & $\begin{array}{c}\Delta \text { Draining } \\
\text { Facility }\end{array}$ & $\begin{array}{l}\Delta \text { Irrigation } \\
\text { Facility }\end{array}$ & $\begin{array}{l}\Delta \text { Land Infra- } \\
\text { structure }\end{array}$ & $\begin{array}{c}\Delta \text { Protective } \\
\text { Forest }\end{array}$ & $\begin{array}{l}\Delta \text { Environ- } \\
\text { mental } \\
\text { Protection }\end{array}$ \\
\hline \multirow{2}{*}{$\begin{array}{l}\Delta(\text { Share of households in largest patrilineal clan } \times \\
\text { One year before a regularly scheduled election })\end{array}$} & 0.703 & 0.607 & 0.228 & 0.003 & 0.052 & -0.015 & 0.004 & 0.029 \\
\hline & $(0.847)$ & $(0.382)$ & $(0.218)$ & $(0.004)$ & $(0.155)$ & $(0.063)$ & $(0.004)$ & $(0.136)$ \\
\hline \multirow{2}{*}{$\begin{array}{l}\Delta(\text { Share of households in largest patrilineal clan } \times \\
\text { the year of a regularly scheduled election }\end{array}$} & 0.498 & 0.002 & -0.116 & 0.010 & -0.050 & -0.041 & $0.006^{*}$ & -0.061 \\
\hline & $(0.488)$ & $(0.195)$ & $(0.142)$ & $(0.010)$ & $(0.049)$ & $(0.044)$ & $(0.003)$ & $(0.056)$ \\
\hline \multirow{2}{*}{$\begin{array}{l}\Delta(\text { Number of deaths within the year } \times \text { One year } \\
\text { before a regularly scheduled election }\end{array}$} & 0.104 & 0.037 & 0.000 & -0.001 & -0.035 & 0.021 & -0.001 & 0.030 \\
\hline & $(0.226)$ & $(0.114)$ & $(0.056)$ & $(0.001)$ & $(0.034)$ & $(0.019)$ & $(0.002)$ & $(0.030)$ \\
\hline \multirow{2}{*}{$\begin{array}{l}\Delta(\text { Number of deaths within the year } \times \text { the year of a } \\
\text { regularly scheduled election }\end{array}$} & -0.085 & -0.044 & -0.013 & -0.001 & -0.004 & 0.022 & -0.002 & -0.006 \\
\hline & $(0.163)$ & $(0.088)$ & $(0.043)$ & $(0.002)$ & $(0.024)$ & $(0.020)$ & $(0.002)$ & $(0.013)$ \\
\hline \multirow[t]{2}{*}{$\Delta$ One year before a regularly scheduled election } & -0.095 & -0.021 & 0.024 & -0.001 & -0.023 & -0.026 & -0.003 & 0.004 \\
\hline & $(0.329)$ & $(0.135)$ & $(0.058)$ & $(0.001)$ & $(0.044)$ & $(0.016)$ & $(0.003)$ & $(0.022)$ \\
\hline \multirow[t]{2}{*}{$\Delta$ The year of a regularly scheduled election } & 0.163 & 0.144 & 0.010 & -0.000 & 0.020 & 0.002 & 0.000 & -0.002 \\
\hline & $(0.237)$ & $(0.098)$ & $(0.045)$ & $(0.001)$ & $(0.040)$ & $(0.020)$ & $(0.001)$ & $(0.016)$ \\
\hline \multirow[t]{2}{*}{$\Delta$ Number of deaths within the year } & 0.029 & -0.028 & -0.007 & -0.000 & -0.007 & -0.022 & 0.001 & 0.003 \\
\hline & $(0.101)$ & $(0.050)$ & $(0.026)$ & $(0.001)$ & $(0.018)$ & $(0.015)$ & $(0.001)$ & $(0.008)$ \\
\hline Number of observations & 495 & 495 & 495 & 495 & 495 & 495 & 495 & 495 \\
\hline
\end{tabular}


Table 6

The Migration Decision and Land Reallocation Risk: Ordinary Least Square and First-Differenced Models

\begin{tabular}{|c|c|c|}
\hline & OLS & FD \\
\hline (Land Reallocation in the Village) $_{\mathrm{t}+1}$ & $\begin{array}{c}-0.016 * * * \\
(0.006)\end{array}$ & $\begin{array}{l}-0.005 * \\
(0.003)\end{array}$ \\
\hline Male×(Time Trend) & $\begin{array}{c}0.010^{* * *} \\
(0.001)\end{array}$ & $\begin{array}{c}0.013 * * * \\
(0.002)\end{array}$ \\
\hline Age $\times($ Time Trend) & $\begin{array}{c}0.002^{* * *} \\
(0.000)\end{array}$ & $\begin{array}{c}-0.009 * * * \\
(0.001)\end{array}$ \\
\hline Age-sq $\times($ Time Trend $)$ & $\begin{array}{c}-0.000 * * * \\
(0.000)\end{array}$ & $\begin{array}{c}0.000 * * * \\
(0.000)\end{array}$ \\
\hline Years of Schooling & $\begin{array}{c}0.012^{* * *} \\
(0.003)\end{array}$ & \\
\hline Father Alive & $\begin{array}{l}0.021 * * \\
(0.010)\end{array}$ & $\begin{array}{c}0.001 \\
(0.006)\end{array}$ \\
\hline Mother Alive & $\begin{array}{l}-0.008 \\
(0.010)\end{array}$ & $\begin{array}{l}-0.001 \\
(0.007)\end{array}$ \\
\hline Number of Siblings & $\begin{array}{c}-0.008 * * * \\
(0.002)\end{array}$ & $\begin{array}{l}-0.002 \\
(0.004)\end{array}$ \\
\hline Land per Capita (log) & $\begin{array}{c}0.003 \\
(0.008)\end{array}$ & $\begin{array}{c}0.001 \\
(0.003)\end{array}$ \\
\hline Consumption per Capita (log) & $\begin{array}{l}-0.001 \\
(0.008)\end{array}$ & $\begin{array}{c}0.002 \\
(0.003)\end{array}$ \\
\hline $\begin{array}{l}\text { Working-Age Females (age 16-60) as Share of } \\
\text { Household Size }\end{array}$ & $\begin{array}{c}0.055^{* * *} \\
(0.013)\end{array}$ & $\begin{array}{l}-0.016 * \\
(0.008)\end{array}$ \\
\hline $\begin{array}{l}\text { Working-Age Males (age 16-60) as Share of } \\
\text { Household Size }\end{array}$ & $\begin{array}{c}0.044^{* * *} \\
(0.015)\end{array}$ & $\begin{array}{c}-0.022 * * * \\
(0.007)\end{array}$ \\
\hline Number of Young Women (19-24) & $\begin{array}{c}0.006 \\
(0.005)\end{array}$ & $\begin{array}{c}0.001 \\
(0.002)\end{array}$ \\
\hline Number of Young Men (21-26) & $\begin{array}{c}0.002 \\
(0.006)\end{array}$ & $\begin{array}{c}0.001 \\
(0.002)\end{array}$ \\
\hline Village Population (log) & $\begin{array}{l}-0.056 \\
(0.049)\end{array}$ & $\begin{array}{l}0.047 * * \\
(0.020)\end{array}$ \\
\hline Village Per Capita Income (log) & $\begin{array}{c}0.001 \\
(0.009)\end{array}$ & $\begin{array}{l}-0.005 \\
(0.005)\end{array}$ \\
\hline Village Land Per Capita (log) & $\begin{array}{l}0.062 * * \\
(0.029)\end{array}$ & $\begin{array}{l}-0.004 \\
(0.008)\end{array}$ \\
\hline Number of Village Cadres & $\begin{array}{c}0.001 \\
(0.002)\end{array}$ & $\begin{array}{c}0.001 \\
(0.001)\end{array}$ \\
\hline
\end{tabular}


Share of Village Cadres with High School

0.013

Education or Above

0.029

(0.014)

Village Land Gini Index

(0.028)

0.024

One Year Before a Regularly Scheduled Election

$0.141^{* *}$

(0.032)

(0.071)

$-0.002$

$-0.005$

(0.004)

The Year of a Regularly Scheduled Election

$(0.007)$

$-0.004$

(0.003)

(0.003)

Time Trend

$-0.013^{*}$

(0.007)

Constant

0.212

$0.182^{* * *}$

(0.301)

(0.019)

Village Fixed Effects

Yes

Yes

Province specific year effects

Number of observations

Yes

Yes

56,342

44,576

Adjusted R2

0.160

0.017

Note: Village clustered robust standard errors in parentheses. ${ }^{* * *} \mathrm{p}<0.01,{ }^{* *} \mathrm{p}<0.05$, * $\mathrm{p}<0.1$. Village fixed effects, interactions of province and year effects are included but not reported. 


\section{Table 7}

The Migration Decision and Land Reallocation Risk:

The First Stage and First Difference IV Models

\begin{tabular}{|c|c|c|}
\hline & First Stage & Second Stage \\
\hline$\Delta$ Village Wide Land Reallocation $(\mathrm{t}+1)$ & & $\begin{array}{c}-0.028^{* * *} \\
(0.010)\end{array}$ \\
\hline Male & $\begin{array}{l}-0.002 \\
(0.001)\end{array}$ & $\begin{array}{c}0.013^{* * *} \\
(0.002)\end{array}$ \\
\hline Age & $\begin{array}{c}0.001 \\
(0.001)\end{array}$ & $\begin{array}{c}-0.009 * * * \\
(0.001)\end{array}$ \\
\hline Age-sq & $\begin{array}{l}-0.000 \\
(0.000)\end{array}$ & $\begin{array}{c}0.000^{* * *} \\
(0.000)\end{array}$ \\
\hline$\Delta$ Father Alive & $\begin{array}{l}-0.008 \\
(0.017)\end{array}$ & $\begin{array}{c}0.001 \\
(0.006)\end{array}$ \\
\hline$\Delta$ Mother Alive & $\begin{array}{c}0.029 \\
(0.020)\end{array}$ & $\begin{array}{l}-0.001 \\
(0.007)\end{array}$ \\
\hline$\Delta$ Number of Siblings & $\begin{array}{c}0.008 \\
(0.015)\end{array}$ & $\begin{array}{l}-0.002 \\
(0.004)\end{array}$ \\
\hline$\Delta$ Land per Capita (log) & $\begin{array}{l}-0.003 \\
(0.021)\end{array}$ & $\begin{array}{c}0.001 \\
(0.003)\end{array}$ \\
\hline$\Delta$ Consumption per capita (log) & $\begin{array}{c}0.001 \\
(0.020)\end{array}$ & $\begin{array}{c}0.002 \\
(0.003)\end{array}$ \\
\hline$\Delta$ Working-Age Females (age 16-60) as Share of Household Size & $\begin{array}{l}-0.023 \\
(0.028)\end{array}$ & $\begin{array}{c}-0.016^{* *} \\
(0.008)\end{array}$ \\
\hline$\Delta$ Working-Age Males (age $16-60$ ) as Share of Household Size & $\begin{array}{l}-0.003 \\
(0.025)\end{array}$ & $\begin{array}{c}-0.022^{* * *} \\
(0.007)\end{array}$ \\
\hline$\Delta$ Number of Young Women (19-24) & $\begin{array}{c}0.008 \\
(0.011)\end{array}$ & $\begin{array}{c}0.001 \\
(0.002)\end{array}$ \\
\hline$\Delta$ Number of Young Men (21-26) & $\begin{array}{l}-0.007 \\
(0.011)\end{array}$ & $\begin{array}{c}0.001 \\
(0.002)\end{array}$ \\
\hline$\Delta$ Village Population (log) & $\begin{array}{c}-0.094 \\
(0.319)\end{array}$ & $\begin{array}{c}0.050 * * \\
(0.024)\end{array}$ \\
\hline$\Delta$ Village Per Capita Income (log) & $\begin{array}{c}-0.332 * * * \\
(0.109)\end{array}$ & $\begin{array}{l}-0.012 * \\
(0.007)\end{array}$ \\
\hline$\Delta$ Village Land Per Capita (log) & $\begin{array}{c}0.528 * * \\
(0.226)\end{array}$ & $\begin{array}{c}0.004 \\
(0.011)\end{array}$ \\
\hline$\Delta$ Number of Village Cadres & $\begin{array}{l}-0.031 \\
(0.021)\end{array}$ & $\begin{array}{c}0.000 \\
(0.001)\end{array}$ \\
\hline $\begin{array}{l}\Delta \text { Share of Village Cadres with High School } \\
\text { Education or Above }\end{array}$ & $\begin{array}{c}0.031 \\
(0.266)\end{array}$ & $\begin{array}{c}0.016 \\
(0.016)\end{array}$ \\
\hline
\end{tabular}


$\Delta$ Number of Deaths within the Year

$\Delta$ One Year Before a Regularly Scheduled Election

$\Delta$ The Year of a Regularly Scheduled Election

$\Delta$ (Share of Households in Largest Patrilineal Clan $\times$ One Year

$\Delta$ (Share of Households in Largest Patrilineal Clan $\times$ Year of a

$\Delta$ (Number of Deaths within the Year $\times$ One Year Before a

$\Delta$ (Number of Deaths within the Year $\times$ Year of a

Observations

Angrist-Pischke Multivariate F-test (p-val)

Over-Identification: Hansen J-Statistic (p-val)

CLR Weak Instrument Robust Test Stat: (p-val)

CLR Weak Instrument Robust Confidence Set

Anderson-Rubin Weak Instrument Robust Test Stat: Chi2 (p-val)

Anderson-Rubin Weak Instrument Robust Confidence Set

44,428
$4.00(0.007)$
$4.127(0.248)$
$11.90(0.002)$
$[-0.066,-0.016]$
$11.12(0.009)$
$[-0.066,-0.017]$

Note: Estimated using limited information maximum likelihood (LIML). Village clustered robust standard errors in parentheses. ${ }^{* * *} \mathrm{p}<0.01,{ }^{* *} \mathrm{p}<0.05,{ }^{*} \mathrm{p}<0.1$. Village fixed effects, interactions of province and year effects are included but not reported. 


\section{Table 8}

Robustness Check: The First Stage and FD-IV Models

Excluding Household Characteristics

\begin{tabular}{|c|c|c|}
\hline \multirow[b]{2}{*}{$\Delta$ Village Wide Land Reallocation ( $t+1)$} & First Stage & Second Stage \\
\hline & & $\begin{array}{c}-0.027 * * * \\
(0.010)\end{array}$ \\
\hline Male & $\begin{array}{l}-0.002 \\
(0.001)\end{array}$ & $\begin{array}{c}0.013^{* * *} \\
(0.002)\end{array}$ \\
\hline Age & $\begin{array}{c}0.001 \\
(0.001)\end{array}$ & $\begin{array}{c}-0.009 * * * \\
(0.001)\end{array}$ \\
\hline Age-sq & $\begin{array}{l}-0.000 \\
(0.000)\end{array}$ & $\begin{array}{l}0.000 * * * \\
(0.000)\end{array}$ \\
\hline$\Delta$ Village Population (log) & $\begin{array}{l}-0.007 \\
(0.011)\end{array}$ & $\begin{array}{c}0.001 \\
(0.002)\end{array}$ \\
\hline$\Delta$ Village Per Capita Income (log) & $\begin{array}{l}-0.095 \\
(0.319)\end{array}$ & $\begin{array}{l}0.050 * * \\
(0.024)\end{array}$ \\
\hline$\Delta$ Village Land Per Capita (log) & $\begin{array}{c}-0.332 * * * \\
(0.109)\end{array}$ & $\begin{array}{l}-0.012 * \\
(0.007)\end{array}$ \\
\hline$\Delta$ Number of Village Cadres & $\begin{array}{l}0.529 * * \\
(0.226)\end{array}$ & $\begin{array}{c}0.004 \\
(0.011)\end{array}$ \\
\hline$\Delta$ Share of Village Cadres with High School & -0.031 & 0.000 \\
\hline \multirow{2}{*}{$\Delta$ Village Land Gini Index } & $\begin{array}{c}(0.021) \\
0.031\end{array}$ & $\begin{array}{c}(0.001) \\
0.016\end{array}$ \\
\hline & $(0.266)$ & $(0.016)$ \\
\hline$\Delta$ Number of Deaths within the Year & $\begin{array}{c}0.305 \\
(0.653)\end{array}$ & $\begin{array}{c}0.041 \\
(0.032)\end{array}$ \\
\hline$\Delta$ One Year Before a Regularly Scheduled Election & $\begin{array}{l}-0.022 \\
(0.050)\end{array}$ & $\begin{array}{l}-0.002 \\
(0.002)\end{array}$ \\
\hline$\Delta$ The Year of a Regularly Scheduled Election & $\begin{array}{c}0.047 \\
(0.077)\end{array}$ & $\begin{array}{c}0.001 \\
(0.002)\end{array}$ \\
\hline $\begin{array}{l}\Delta \text { (Share of Households in Largest Patrilineal Clan } \times \text { One Year } \\
\text { Before a Regularly Scheduled Election) }\end{array}$ & $\begin{array}{l}-0.530 * * \\
(0.221)\end{array}$ & \\
\hline $\begin{array}{l}\Delta \text { (Share of Households in Largest Patrilineal Clan } \times \text { Year of a } \\
\text { Regularly Scheduled Election) }\end{array}$ & $\begin{array}{c}-0.070 * * \\
(0.035)\end{array}$ & \\
\hline $\begin{array}{l}\Delta \text { (Number of Deaths within the Year } \times \text { One Year Before a } \\
\text { Regularly Scheduled Election) }\end{array}$ & $\begin{array}{l}0.309^{*} \\
(0.170)\end{array}$ & \\
\hline $\begin{array}{l}\Delta \text { (Number of Deaths within the Year } \times \text { Year of a } \\
\text { Regularly Scheduled Election) }\end{array}$ & $\begin{array}{c}0.118 * * * \\
(0.036)\end{array}$ & \\
\hline Observations & & \\
\hline Angrist-Pischke Multivariate F-test ( $p$-val) & & \\
\hline Over-Identification: Hansen J-Statistic ( $p$-val) & & 39) \\
\hline CLR Weak Instrument Robust Test Stat: (p-val) & & 2) \\
\hline CLR Weak Instrument Robust Test Confidence Sets & & $15]$ \\
\hline
\end{tabular}


Anderson-Rubin Weak Instrument Robust Test Stat: Chi2 ( $p$-val)

$10.65(0.001)$

Anderson-Rubin Weak Instrument Robust Test Confidence Sets

$[-0.066,-0.017]$

Note: Village clustered robust standard errors in parentheses. $* * * \mathrm{p}<0.01,{ }^{* *} \mathrm{p}<0.05,{ }^{*} \mathrm{p}<0.1$. Village fixed effects, interactions of province and year effects are included but not reported. 


\section{Appendix Table A1: Regulations Related to the Organizational Structure and the Timing of Village Election:}

Anhui, Henan, Jiangsu, and Shanxi

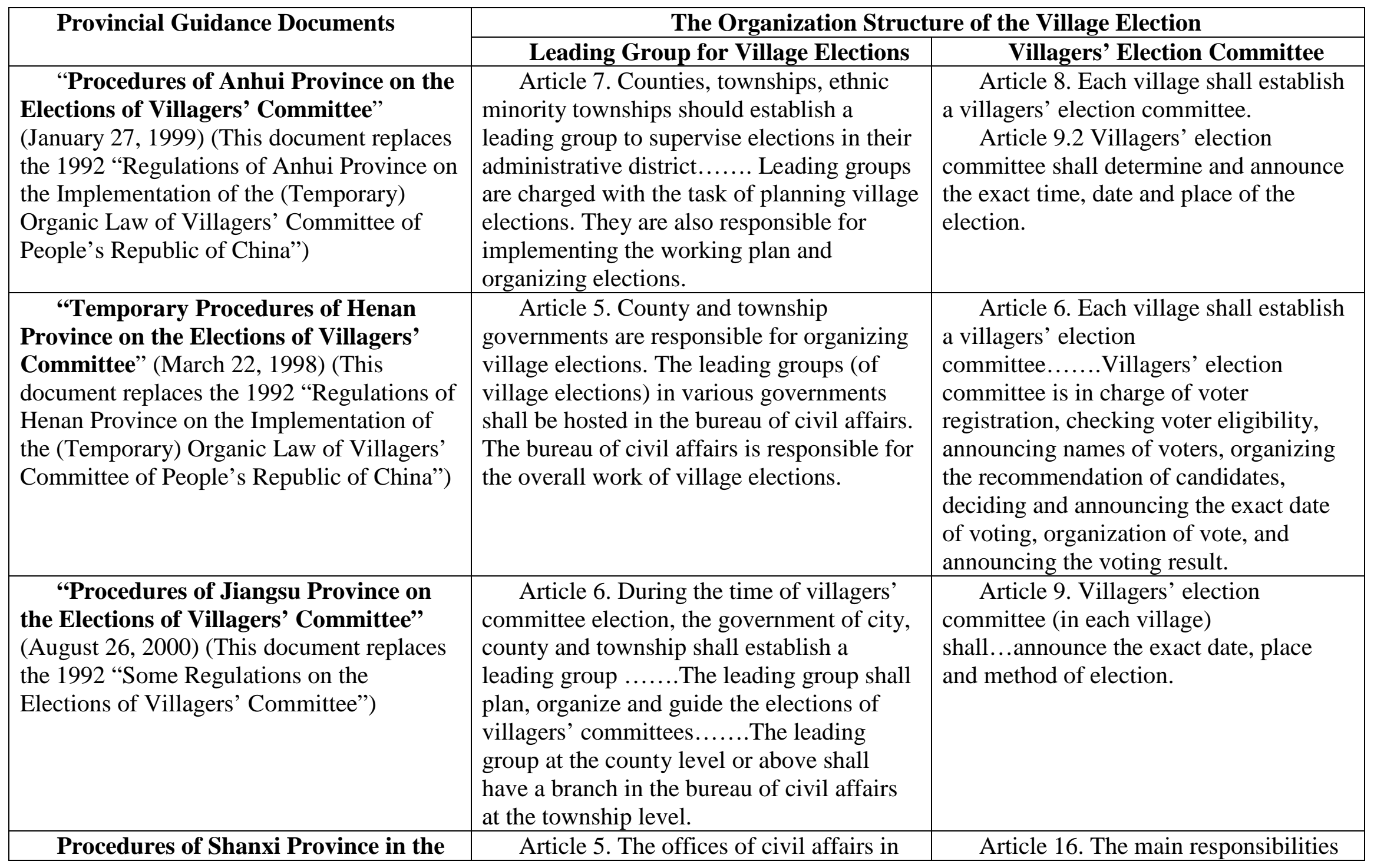




\begin{tabular}{|c|c|c|}
\hline $\begin{array}{l}\text { Implementation of Organic Law of } \\
\text { Villagers' Committee of the People’s } \\
\text { Republic of China (September 26, 1999) } \\
\text { (This document replaces the } 1991 \\
\text { "Procedures of Shanxi Province on } \\
\text { Organization of Villagers' Committee”.) }\end{array}$ & $\begin{array}{l}\text { the county or above-county governments } \\
\text { are in charge of implementing the Organic } \\
\text { Law of Villagers' Committee and this } \\
\text { regulatory document. } \\
\text { Article 14. Under the leadership of the } \\
\text { provincial government, at the time of the } \\
\text { election of villagers' committee, county and } \\
\text { township shall establish leading groups, } \\
\text { organizing and supervising elections in their } \\
\text { administrative district. }\end{array}$ & $\begin{array}{l}\text { of village election committee } \\
\text { include: ........determining and } \\
\text { announcing the exact time and date of } \\
\text { election....... }\end{array}$ \\
\hline
\end{tabular}

